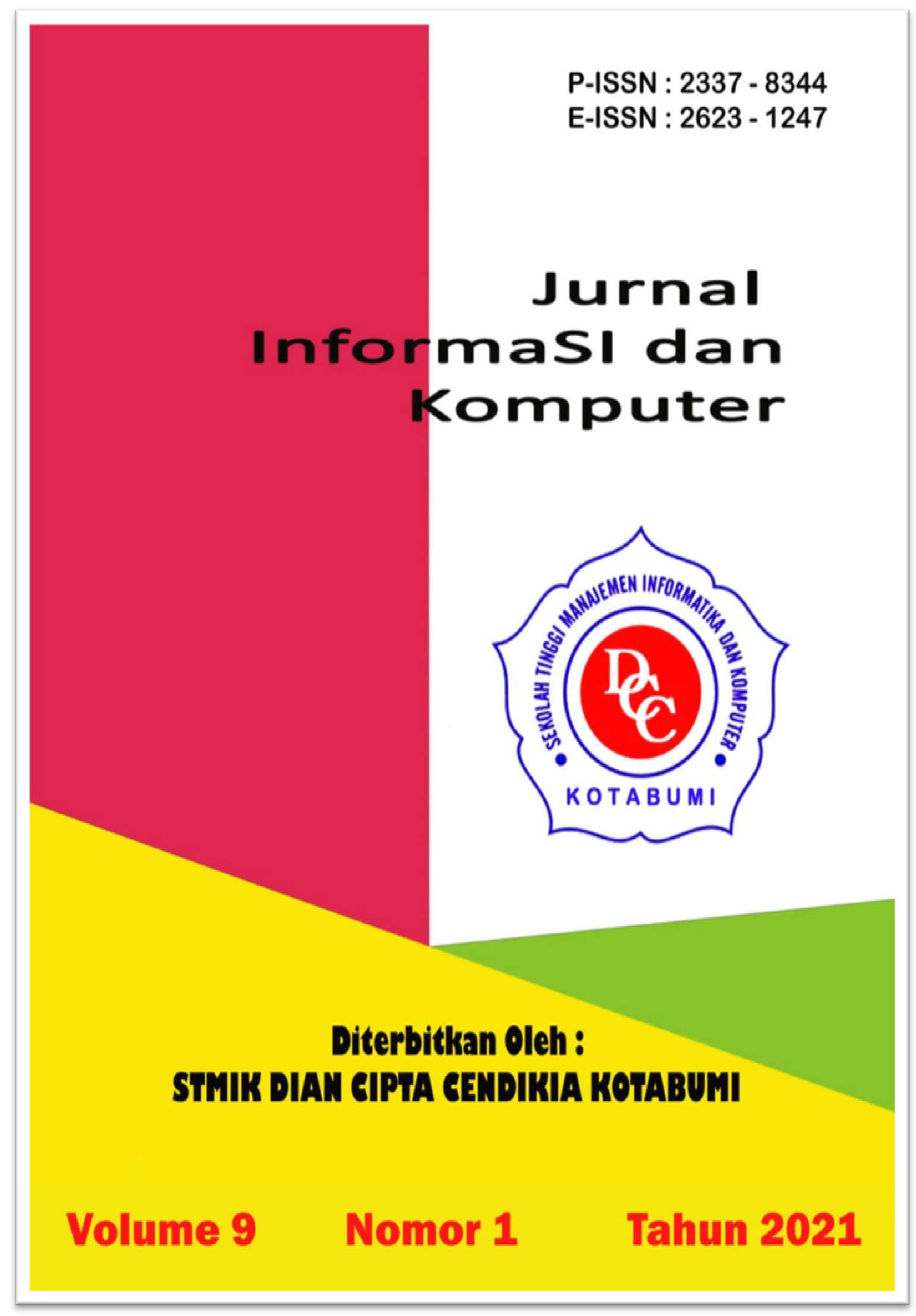




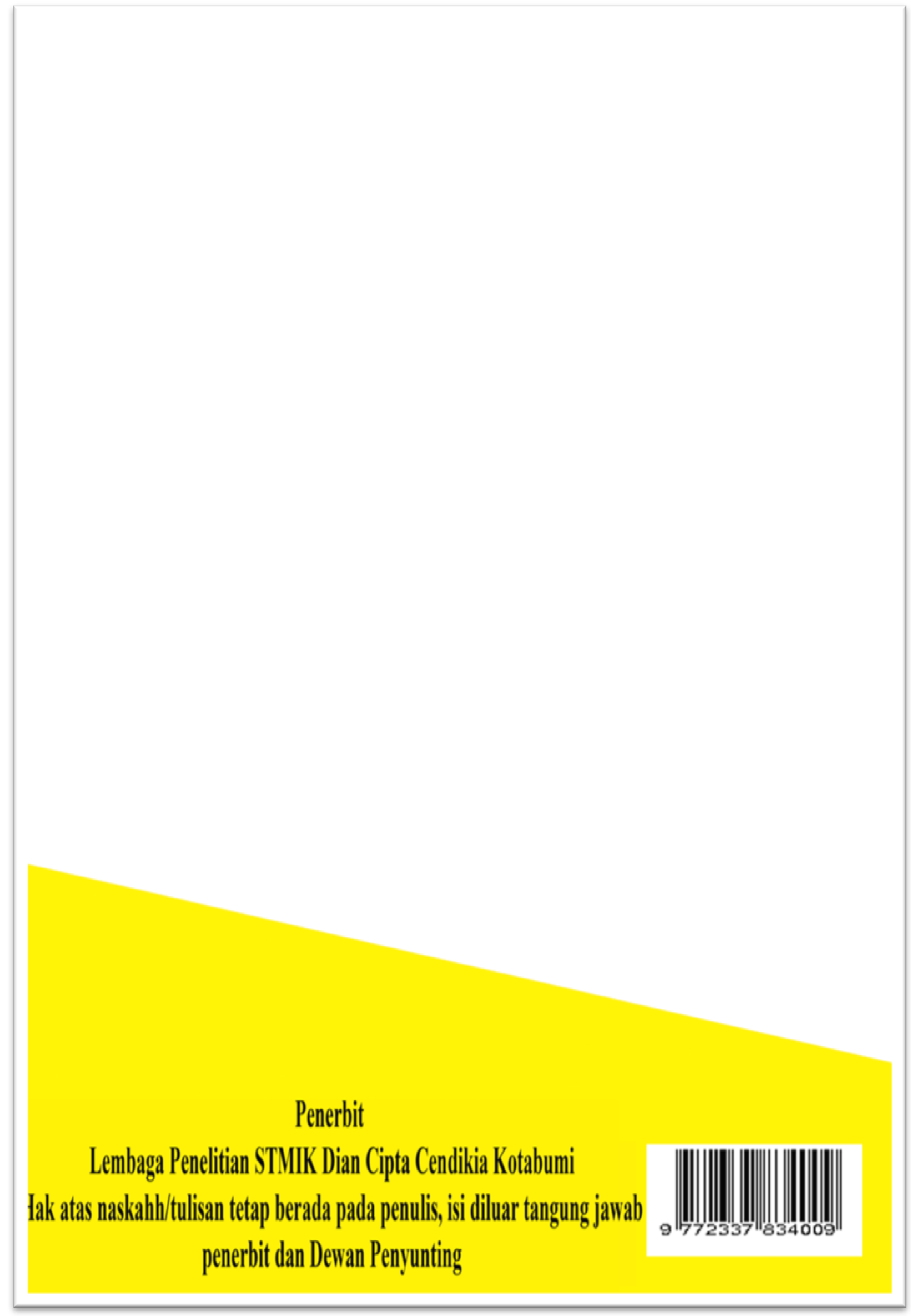




\section{JURNAL INFORMASI DAN KOMPUTER}

\section{Volume 9 Nomor 1 April 2021}

Jurnal Informasi dan Komputer merupakan Sarana informasi ilmu pengetahuan, Tekhnologi dan Komunikasi yang berupa hasil penelitian, tulisan ilmiah, Ataupun studi pustaka. Jurnal ini terbit dua kali setahun pada bulan April dan Oktober. Berisi hasil penelitian ilmiah di bidang informatika yang bertujuan untuk menghubungkan adanya kesenjangan antar kemajuan teknologi dan hasil penelitian. Jurnal ini di terbitkan pertama kali pada tahun 2013.

Penanggung Jawab:

Ketua STMIK Dian Cipta Cendikia

Kotabumi

\section{Pembina:}

Ketua STMIK Dian Cipta Cendikia

Kotabumi

Ketua Lembaga Penelitian STMIK Dian

Cipta Cendikia Kotabumi

\section{Pimpinan Redaksi}

Dwi Marisa Efendi,.S.Kom.,M.Ti

\section{Redaksi pelaksana}

Rustam,.S.Kom,.M.Ti (STMIK Dian

Cipta Cendikia Kotabumi)

Nurmayanti M.Kom (STMIK Dian

Cipta Cendikia Kotabumi)

Sukatmi,.S.Kom., M.Kom (AMIK DCC

Bandar Lampung)

Sampurna Dadi Riskiono,M.Kom

(Universitas Teknokrat Indonesia)

Ifo Wahyu

Pratama,S.Kom.,M.Ti(AMIK MASTER

Lampung)

\section{Mitra Bestari}

Merri Parida.,M.Kom (STMIK Dian

Cipta Cendikia Kotabumi)

Amarudin,S.Kom.,M.Eng (Universitas

Teknokrat Indonesia)

Didi Susianto.,S.T.,M.Kom (AMIK

DCC Bandar Lampung)

Alhibarsyah.,S.T.,M.Kom (Stmik Tunas

Bangsa Bandar Lampung)

Kemal Farouq Mauladi

.,S.Kom.,M.Kom (Universitas Islam

Lamongan)

Agus Setiawan S.Pd.,M.Eng

(Universitas Muhammadiyah

Lamongan)

Ferrly Ardhy, S.Kom., M.Ti

(Universitas Aisyah Pringsewu)

\section{Penerbit :}

STMIK Dian Cipta Cendikia Kotabumi Bekerja Sama Dengan LPPM STMIK

Dian Cipta Cendikia Kotabumi.

\section{Alamat Redaksi/Penerbit:}

Jl. Negara No. 3 Candimas Kotabumi

Lampung Utara

No Telpon/Fax 072423003

Email : lppm-stmik@dcc.ac.id 


\section{PENGANTAR REDAKSI}

Puji syukur dipanjatkan kehadirat Tuhan Yang Maha Esa, atas karunia dan limpahan rahmatnya Jurnal Informasi dan komputer (JIK) STMIK Dian Cipta Cendikia Kotabumi ini dapat terwujud, sehinga dapat di terbit 2 (dua) kali dalam setahun ini merupakan suatu wadah untuk penyebar luasan hasil-hasil penelitian, studi pustaka, karya ilmiah yang berkaitan dengan Informatika dan Komputer khususnya bagi dosen-dosen STMIK Dian Cipta Cendikia Kotabumi serta umumnya para cendikiawan, praktisi, peneliti ilmu Informatika dan Komputer.

Harapan dengan diterbitkannya Jurnal Informasi dan Komputer (JIK) ini sebagai salah satu bentuk sumbangan pemikiran dalam pengembangan ilmu informatika dan komputer yang berkaitan dengan kajian-kajian di bidang tekhnologi informatik, Komunikasi Data dan Jaringan Komputer, perancangan dan Rekayasa Perangkat Lunak, serta ilmu-ilmu yang terkait dengan bidang Informatika dan Komputer lainnya.

Berkenaan dengan harapan tersebut, kepada para peneliti, dosen dan praktisi yang memiliki hasil-hasil penelitian, kajian pustaka, karya ilmiah dalam bidang tersebut diatas, dengan bangga redaksi Jurnal Informatika dan Komputer (JIK) menerima naskah ringkasan untuk dimuat pada jurnal Informasi dan Komputer (JIK) STMIK Dian Cipta Cendikia Kotabumi dengan berpedoman pada penulisan naskah jurnal sebagaimana dilampirkan pada halaman belakang (Bagian kulit dalam) buku jurnal ini.

Mutu dari suatu jurnal ilmiah tidak hanya ditentukan oleh para pengelolanya saja, tetapi para penulis dan pembaca jualah yang mempunyai peranan besar dalam meningkatkan mutu jurnal Informatika dan Komputer ini. Merujuk pada realita ini kamu sangat mengharapkan peran aktif dari peneliti untuk bersama-sama menjaga dan memelihara keberlangsungan dari jurnal Informatika dan Komputer STMIK Dian Cipta Cendikia Kotabumi ini. Yang juga tidak kalah pentingnya dari partisipasi tersebut diatas, adalah saran dan kritik yang membangun dari pembaca yang budiman agar kiranya dapat disampaikan langsung kepada redaksi JIK. Saran dan kritik yang membangun akan dijadikan masukan dan pertimbangan yang sangat berarti guna peningkatan mutu dan kualitas Jurnal Informatika dan Komputer STMIK Dian Cipta Cendikia Kotabumi.

Tak lupa diucapkan terima kasih yang tak terhingga atas perhatian dan kerjasama dari semua pihak yang tak dapat disebutkan satu persatu hingga dapat diterbitkan nya Jurnal Informasi dan Komputer (JIK) STMIK Dian Cipta Cendikia Kotabumi. Semoga apa yang telah diperbuat untuk kebaikan akan menjadi amal ibadah, amin.

Kotabumi, 25 April 2021

Dewan Redaksi 


\title{
JURNAL INFORMASI DAN KOMPUTER
}

\author{
VOL. 9 NO. 1 THN. 2021
}

\begin{abstract}
DAFTAR ISI
Implementasi Framework ITIL 3 Pada Aplikasi Pelayanan Pelanggan Terpadu PT. PLN (PERSERO)

Wilayah Kotabumi

Ferly Ardhy, Dwi Marisa Efendi, Mitha Franciska, Nur Aminudin, Rustam,

Abdullah Umar Faqih Al Ikhsani

(Universitas Aisyah Pringewu, STMIK Dian Cipta Cendikia Kotabumi)

Penerapan Metode Naive Bayes Dalam Menentukan Pengaruh Keaktifan Mahasiswa Berrorganisasi Terhadap

Presentasi Belajar

Debby Febriani R Saragih, Heru Satria Tambunan, Jaya Tata Hardinata

(STIKOM Tunas Bangsa Pematangsiantar Indonesia)
\end{abstract}

Penerapan Data Mining Untuk Prediksi Penjualan Pupuk Dengan Metode Algoritma Apriori

Dwi Marisa Efendi, Sidik Rahmatullah, Asep Afandi, Pakarti Riswanto, Nurmayanti

(STMIK Dian Cipta Cendikia Kotabumi)

Sistem Informasi Pelayanan Administrasi Surat Pengantar Berbasis Website Dengan Framework Codeigniter Guna Meningkatkan Kualitas Pelayanan Pada Desa Tambaksari Kidul Kabupaten Banyumas

Endang Setyawati1, Suyudi, Foustino Asprilla Gunantara, Hadion Wijoyo

(STIKOM Yos Sudarso Purwokerto, STMIK Dharmapala Riau)

Implementasi Algoritma Naive Bayes Untuk Menentukan Tingkat Kedisiplinan Siswa

Sidik Rahmatullah, Iko Prastiyo

(STMIK Dian Cipta Cendikia Kotabumi)

Pemanfaatan Framework Codeigniter Untuk Membangun Aplikasi Display Produk Di Alfamart Rajabasa Yuli Syafitri1, Yudi Dwi Pramudya, Muhammad Rasid

(AMIK Dian Cipta Cendikia, STMIK Tunas Bangsa)

Perbandingan Metode Nearest Neighbor, Ward Dan K-Means Dalam Menentukan Cluster Data Kinerja

Kantor Unit Bank Abc

Bambang Suprapto, Henry Simanjuntak, Sulasminarti

(AMIK Dian Cipta Cendikia Pringsewu)

“Aplikasi Computer Basic Test (Cbt) Pada Smk Ma’arif Sukoharjo Kec. Pringsewu Kab. Pringsewu Berbasis Web” Rima Mawarni, Dewi Triyanti. Ardiansyah

(STMIK Dian Cipta Cendikia Kotabumi, AMIK Dian Cipta Cendikia Pringsewu)

Pengembangan Aplikasi Pencarian Guru Privat Editing Video Berbasis Android

Nurhasan Nugroho, Riduwan Napianto, Imam Ahmad, Wahyu Ariya Saputra

(Universitas Bina Bangsa, Universitas Teknokrat Indonesia) 
Sistem Penilaian Kinerja Karyawan Dengan Menggunakan Metode Simple Additive Weighting (Saw) Darsin, Desi Triyana

(Universitas Megou Pak Tulang Bawang).

Aplikasi Belajar Dasar-Dasar Bahasa Isyarat Berbasis Android Ngajiyanto, Sigit Mintoro, Melpin Aprido Jenius,

(STMIK Dian Cipta Cendikia kotabumi) 


\title{
IMPLEMENTASI ALGORITMA NAIVE BAYES UNTUK MENENTUKAN TINGKAT KEDISIPLINAN SISWA
}

\author{
Sidik Rahmatullah ${ }^{1}$, Supriyanto $^{2}$, Rustam $^{3}$, Merri Parida $^{4}$, Iko Prastiyo ${ }^{5}$ \\ STMIK DCC Kotabumi ${ }^{12345}$ \\ J1.Negara Nomor 03 Candimas Kotabumi Lampung Utara \\ E-mail: sidik@dcc.ac.id ${ }^{1}$, supriyanto@dcc.ac.id, rustam@dcc.ac.id,meri@dcc.ac.id, \\ ikoprastiyo30@gmail.com
}

\begin{abstract}
ABSTRAK
Sekolah yang memiliki misi untuk mempersiapkan siswa yang berkualitas dan handal dengan menampung berbagai macam latar belakang dan juga kepribadian siswa yang berbeda-beda. Dengan adanya perbedaan tersebut mendorong para siswa untuk melakukan tindakan pelanggaran di sekolah. Pelanggaran-pelanggaran tersebut menyebabkan terhambatnya kegiatan belajar di sekolah, dan menurunkan kualitas sekolah. Untuk membantu dan meminimalisir terjadinya pelangaran di sekolah, maka penelitian ini di lakukan dengan menggunakan teknik data mining dengan metode naïve bayes classifier dan metode pengembangan sistemnya adalah waterfall. Dalam pengimplementasiannya akan di terapkan ke dalam pogram vb.net dengan tool visual studio 2019 dan menggunakan database MYSQLi. Adapun atribut yang akan di gunakan yaitu jenis kelamin, jenis tinggal, asal sekolah, jarak rumah, pendidikan ayah, pekerjaan ayah, penghasilan ayah, pendidikan ibu, pekerjaan ibu, dan penghasilan ibu. Penerapan sistem ini bertujuan membantu sekolah dalam pengklasifikasian tingkat kedisiplinan siswa dan menghasilkan output pengelompokan tingkat kedisiplinan siswa dengan kelas tinggi dan rendah. Dari hasil uji coba data testing yang berjumlah 8 record dengan 10 variabel menghasilkan keakuratan sebesar $63 \%$ dan eror sebesar $38 \%$, sehingga dapat di simpulkan bahwa sistem ini sudah baik untuk di lihat dari data yang di dapat berdasarkan kesesuaiannya.
\end{abstract}

Kata Kunci: data mining, tingkat kedisiplinan, naïve bayes, vb.net, waterfall.

\begin{abstract}
Senior High School is a school that has a mission to prepare qualified and reliable students by accommodating a variety of backgrounds and different student personalities. With these differences encourage students to commit acts of violation in school. These violations cause delays in learning activities in schools, and reduce the quality of schools. To help and minimize the occurrence of violations in schools, this research was conducted using data mining techniques with the naïve Bayes classifier method and the system development method is waterfall. The implementation will be applied to the vb.net program with the 2019 visual studio tool and using the MYSQLi database. The attributes that will be used are gender, type of residence, school origin, distance of the house, father's education, father's occupation, father's income, mother's education, mother's occupation, and mother's income. The application of this system aims to assist schools in classifying the level of student discipline and produce outputs of grouping levels of student discipline with high and low classes. From the test results of testing data which amounted to 8 records with 10 variables produce an accuracy of $63 \%$ and an error of $38 \%$, so it can be concluded that this system is good to be seen from the data obtained based on its suitability.
\end{abstract}

Keywords: data mining, discipline level, Naïve Bayes, vb.net, waterfall.

\section{PENDAHULUAN}

Pada saat ini Perkembangan pada zaman modern sangatlah meningkat, terutama perkembangan pada sisi pendidikan.
Pendidikan merupakan sarana terpenting untuk memajukan sebuah kualitas manusia. Dengan demikian, pendidikan menjadi tolak ukur untuk meningkatkan kualitas manusia yang berdasarkan pengalaman belajar yang telah di 
perolehnya. Adapun salah satu tempat yang dapat di gunakan untuk menempuh pendidikan di antaranya yaitu Sekolah Menengah Kejuruan (SMK).

SMK adalah Sekolah pendidikan menengah kejuruan yang memiliki misi untuk mempersiapkan siswa yang berkualitas dan juga memiliki keahlian sebelum memasuki dunia kerja. Salah satunya yaitu SMK Swasta Muhammadiyah Abung Semuli yang menampung siswa dengan berbagai macam latar belakang dan juga kepribadian yang berbeda-beda. Dengan adanya berbagai macam latar belakang dan kepribadian siswa yang berbeda-beda tersebut, ini akan mempengaruhi tingkat kedisiplinan siswa, apa bila tingkat kedisiplinan siswa rendah maka siswa berpotensi melakukan pelanggaran.

Kedisiplinan siswa merupakan suatu bentuk keadaan tertib atau patuh yang terdapat di lingkungan sekolah. Kedisiplinan memiliki dampak yang baik dalam memperlancar kegiatan belajar di sekolah. Dan dengan demikian, tanpa adanya sebuah kedisiplinan dan pengaruh perilaku yang disiplin, siswa disekolah pastinya akan berprilaku seenaknya sendiri (Nurabadi et al., 2020).

Perubahan Penurunan tingkat kedisiplinan biasanya ditandai dengan semakin meningkatnya poin pelanggaran setiap siswa. Di SMK Swasta Muhammadiyah Abung Semuli penurunan tingkat kedisiplinan di tunjukan dari banyaknya jumlah poin siswa yang telah melanggar peraturan di sekolah. Adapun data rekapanya di tahun 2019 terdapat sebanyak 682 kasus pelanggaran dimana bulan november tercatat sebanyak 291 pelanggaran, bulan januari tercatat sebanyak 148 pelanggaran, dan bulan februari tercatat sebanyak 243 pelanggaran. Adapun komposisi jenis pelanggaran secara keseluruhan tercatat alfa sebanyak $78,70 \%$, bolos sebanyak $8,60 \%$, izin sebanyak $6,00 \%$, sakit sebanyak $6,10 \%$, dan terlambat sebanyak $0,40 \%$.

perubahan tingkat kedisiplinan yang sering terjadi di Di SMK Swasta Muhammadiyah Abung Semuli di sebabkan oleh beberapa faktor pelanggaran yang sudah terjadi. Faktorfaktor yang dapat menimbulkan terjadinya sebuah pelanggaran tata tertib di sekolah yaitu ada dua diantaranya faktor internal siswa dan faktor eksternal siswa (Arsaf, 2015).
Menurut Hasibuan et al., (2017) "Data mining merupakan sebuah teknik penggabungan antara teknik analisis data dan menemukan sebuah pola-pola yang cukup penting pada sebuah data. Secara sederhananya, pengembangan data atau data mining dapat di katakan sebagai proses penyeleksi, eksplorasi dan juga pemodelan dari beberapa sejumlah besar data untuk menemukan sebuah pola-pola kecenderungan yang biasanya tidak pernah disadari keberadaannya. Di dalam data mining, data Tersebut di simpan secara elektronik dan diproses dengan cara otomatis oleh komputer menggunakan sebuah teknik dan perhitungan tertentu. Data mining tersebut akan menjadi tolak ukur ataupun acuan untuk sebuah pengambilan keputusan". Maka penerapan data mining pada SMKS Muhammadiyah bertujuan untuk memprediksi tingkat kedisiplinan siswa baru yang memiliki potensi kedisiplinan yang rendah, yang kedepannya akan di lakukan bimbingan dan binaan terhadap sekolah, sehingga dapat membantu pihak sekolah dalam memprediksi dan juga meminimalisir siswa yang akan melakukan pelanggaran tata tertib di sekolah.

Menurut Studi et al., (2020), NBC merupakan sebuah algoritma klasifikasi yang dapat kita gunakan untuk melakukan prediksi terhadap probabilitas suatu keanggotaan pada class dengan menerapkan teorema Bayes.

\section{METODE PENELITIAN}

\subsection{Teknik Pengumpulan Data}

\section{Observasi}

Observasi dilakukan langsung dengan mengamati siswa di SMKS Muhammadiyah Abung Semuli.

\section{Wawancara}

Wawancara dilakukan dengan guru BK (Bimbingan Konseling) dengan menanyakan masalah-masalah yang ada pada saat analisa data siswa.

\section{Studi Pustaka}

Penulis melakukan pengumpulan dengan melakukan pengkajian melalui berbagai referensi dari jurnal yang ada di perpustakaan, 
dan dari internet, serta pelengkap sumbersumber lainya yang berhubungan.

\subsubsection{Penerapan Metode Naive Bayes}

Metode Naive bayes yaitu metode yang dapat di gunakan untuk memprediksi dengan menggunakan probabilitas yang sederhana di dalam mencari sebuah tingkat keakurasian berdasarkan teorema bayes. Perhitungan ini dapat diterapkan dengan memperhitungkan sebuah independensi yang cukup kuat. Independensi yang cukup kuat ini adalah keadaan pada sebuah data yang tidak saling terkait atau saling bebes satu sama lainnya. Apabila atribut yang tidak saling terkait (independent) di berikan $k$ maka probabilitas tersebut dapat di berikan sebagai berikut:

$$
\mathrm{P}(\mathrm{x} 1, \ldots, \mathrm{xk} \mid \mathrm{C}=\mathrm{P}(\mathrm{x} 1 \mid \mathrm{C}) \mathrm{x} \ldots \mathrm{xP}(\mathrm{xk} \mid \mathrm{C})
$$

Pada penggunaan penerapan pada metode naive bayes ini, langkah awal yang dapat di lakukan yaitu penetuan sebuah data training yang di ambil dari data primer siswa kelas X, XI, dan XII SMKS Muhammadiyah Abung Semuli. Adapun variabel/atribut yang akan di gunakan dan di diskritasikan untuk mengklasifikasi data siswa tersebut yaitu:

Tabel 1. Diskritasi Variabel

\begin{tabular}{|c|c|c|}
\hline $\begin{array}{l}\text { Nama } \\
\text { atribut }\end{array}$ & interval & $\begin{array}{l}\text { keteranga } \\
\text { n }\end{array}$ \\
\hline \multirow{2}{*}{$\begin{array}{l}\text { Jenis } \\
\text { kelami } \\
\mathrm{n}\end{array}$} & $\mathrm{L}$ & Laki-laki \\
\hline & $\mathrm{P}$ & Perempuan \\
\hline \multirow[t]{2}{*}{$\begin{array}{l}\text { Jenis } \\
\text { tinggal }\end{array}$} & Bersama orang tua & $\begin{array}{l}\text { Bersama } \\
\text { orang tua }\end{array}$ \\
\hline & Kos,asrama,saudara,dll & Lain-lain \\
\hline \multirow[t]{3}{*}{$\begin{array}{l}\text { Asal } \\
\text { sekola } \\
\mathrm{h}\end{array}$} & $\begin{array}{l}\text { SMP Negeri } 1 \text { Abung } \\
\text { Semuli, SMP Negeri } 4 \\
\text { Abung Timur, SMP } \\
\text { Negeri } 2 \text { Abung Semuli }\end{array}$ & $\begin{array}{l}\text { SMP } \\
\text { NEGERI }\end{array}$ \\
\hline & $\begin{array}{l}\text { SMP Bhakti Angkasa } 1 \\
\text { Semuli Jaya, SMP Al } \\
\text { Amin Abung Surakarta }\end{array}$ & $\begin{array}{l}\text { SMP } \\
\text { SWASTA }\end{array}$ \\
\hline & $\begin{array}{l}\text { MTs Bhakti Angkasa } \\
\text { Semuli, MTs Al } \\
\text { Muhajirin Bandar } \\
\text { Sakti, MTs Al } \\
\text { Khoiriyah Sidorahayu }\end{array}$ & MTS \\
\hline \multirow[t]{3}{*}{$\begin{array}{l}\text { Jarak } \\
\text { rumah }\end{array}$} & Kurang dari $5 \mathrm{~km}$ & $\begin{array}{l}\text { Kurang } \\
\text { dari } 5 \mathrm{~km}\end{array}$ \\
\hline & 5 sampai $10 \mathrm{~km}$ & $\begin{array}{l}5 \text { sampai } \\
10 \mathrm{~km}\end{array}$ \\
\hline & Lebih dari $10 \mathrm{~km}$ & Lebih dari \\
\hline
\end{tabular}

\begin{tabular}{|c|c|c|}
\hline & & $10 \mathrm{~km}$ \\
\hline \multirow{3}{*}{$\begin{array}{l}\text { Pendid } \\
\text { ikan } \\
\text { ayah }\end{array}$} & $\mathrm{SD} /$ sederajat & $\begin{array}{l}\text { Pendidikan } \\
\text { dasar }\end{array}$ \\
\hline & SMP / sederajat & $\begin{array}{l}\text { Pendidikan } \\
\text { menengah }\end{array}$ \\
\hline & $\begin{array}{l}\text { SMA sederajat, D1, } \\
\text { D2, D3, S1, S2, S3, } \\
\text { dan lain-lain }\end{array}$ & $\begin{array}{l}\text { Pendidikan } \\
\text { tinggi }\end{array}$ \\
\hline $\begin{array}{l}\text { Nama } \\
\text { atribut }\end{array}$ & interval & keterangan \\
\hline \multirow{8}{*}{$\begin{array}{l}\text { Pekerja } \\
\text { an } \\
\text { ayah }\end{array}$} & buruh & buruh \\
\hline & Petani & Petani \\
\hline & pedagang & pedagang \\
\hline & wiraswasta & wiraswasta \\
\hline & Pegawai swasta & $\begin{array}{l}\text { Pegawai } \\
\text { swasta }\end{array}$ \\
\hline & Pegawai negeri & $\begin{array}{l}\text { Pegawai } \\
\text { negeri }\end{array}$ \\
\hline & Tidak bekerja & $\begin{array}{l}\text { Tidak } \\
\text { bekerja }\end{array}$ \\
\hline & Sudah meninggal & $\begin{array}{l}\text { Sudah } \\
\text { meninggal }\end{array}$ \\
\hline \multirow{4}{*}{$\begin{array}{l}\text { Pengha } \\
\text { silan } \\
\text { ayah }\end{array}$} & Kurang dari 1 juta & $\begin{array}{l}\text { Kurang } \\
\text { dari } 1 \text { juta }\end{array}$ \\
\hline & 1 juta sampai 2 juta & $\begin{array}{lr}1 & \text { juta } \\
\text { sampai } & 2 \\
\text { juta } & \\
\end{array}$ \\
\hline & lebih dari 2 juta & $\begin{array}{l}\text { lebih dari } 2 \\
\text { juta }\end{array}$ \\
\hline & Tidak berpenghasilan & $\begin{array}{l}\text { Tidak } \\
\text { berpenghas } \\
\text { ilan }\end{array}$ \\
\hline \multirow{3}{*}{$\begin{array}{l}\text { Pendid } \\
\text { ikan } \\
\text { ibu }\end{array}$} & $\mathrm{SD} /$ sederajat & $\begin{array}{l}\text { Pendidikan } \\
\text { dasar }\end{array}$ \\
\hline & SMP / sederajat & $\begin{array}{l}\text { Pendidikan } \\
\text { menengah }\end{array}$ \\
\hline & $\begin{array}{l}\text { SMA sederajat, D1, } \\
\text { D2, D3, S1, S2, S3, } \\
\text { dan lain-lain }\end{array}$ & $\begin{array}{l}\text { Pendid } \\
\text { ikan } \\
\text { tinggi }\end{array}$ \\
\hline \multirow{7}{*}{$\begin{array}{l}\text { Pekerja } \\
\text { an ibu }\end{array}$} & buruh & buruh \\
\hline & Petani & Petani \\
\hline & pedagang & pedagang \\
\hline & wiraswasta & wiraswasta \\
\hline & Pegawai swasta & $\begin{array}{l}\text { Pegawai } \\
\text { swasta }\end{array}$ \\
\hline & Pegawai negeri & $\begin{array}{l}\text { Pegawai } \\
\text { negeri }\end{array}$ \\
\hline & Tidak bekerja & $\begin{array}{l}\text { Tidak } \\
\text { bekerja }\end{array}$ \\
\hline \multirow{2}{*}{$\begin{array}{l}\text { Pengha } \\
\text { silan } \\
\text { ibu }\end{array}$} & Kurang dari 1 juta & $\begin{array}{l}\text { Kurang } \\
\text { dari } 1 \text { juta }\end{array}$ \\
\hline & 1 juta sampai 2 juta & $\begin{array}{lr}1 & \text { juta } \\
\text { sampai } & 2 \\
\text { juta } & \\
\end{array}$ \\
\hline
\end{tabular}




\begin{tabular}{|l|l|l|}
\hline \multirow{2}{*}{} & lebih dari 2 juta & $\begin{array}{l}\text { lebih dari } 2 \\
\text { juta }\end{array}$ \\
\cline { 2 - 3 } & Tidak berpenghasilan & $\begin{array}{l}\text { Tidak } \\
\text { berpenghas } \\
\text { ilan }\end{array}$ \\
\hline $\begin{array}{l}\text { klasifik } \\
\text { asi }\end{array}$ & tinggi & tinggi \\
\cline { 2 - 3 } & rendah & rendah \\
\hline
\end{tabular}

\subsubsection{Perhitungan manual naïve bayes}

\section{A. Data testing yang pertama}

1. Hitung jumlah kelas atau label $\mathrm{P}(\mathrm{Y}=$ Tinggi $)=65 / 80$ "jumlah data potensi yang tinggi pada data training di bagi dengan jumlah total data training".

$\mathrm{P}(\mathrm{Y}=$ Rendah $)=15 / 80$ "jumlah data potensi yang rendah pada data training di bagi dengan jumlah total data training".

2. jumlah kasus yang sama dengan class yang sama

$\mathrm{P}($ jenis kelamin $=$ laki-laki $\mid \mathrm{y}=$ tinggi $)=49 / 65$

$\mathrm{P}($ jenis kelamin=laki-laki $\mid \mathrm{y}=\mathrm{rendah})=14 / 15$

$\mathrm{P}(\mathrm{jenis}$ tinggal=bersama orang tua $\mid y=$ tinggi $)=61 / 65$

$\mathrm{P}($ jenis tinggal = bersama orang tua $\mathrm{y}=$ rendah $)=15 / 15$

$\mathrm{P}($ asal sekolah $=\mathrm{MTS} \mid \mathrm{y}=$ ting $\mathrm{i})=16 / 65$

$\mathrm{P}($ asal sekolah $=\mathrm{MTS} \mid \mathrm{y}=\mathrm{rendah})=7 / 15$

$\mathrm{P}($ jarak rumah=lebih dari $10 \mathrm{~km}$ |y=tinggi $)=15 / 65$

$\mathrm{P}($ jarak rumah $=$ lebih dari $10 \mathrm{~km}$ $\mid y=$ rendah $)=10 / 15$

$\mathrm{P}$ (pendidikan ayah=pendidikan dasar |y=tinggi $=38 / 65$

$\mathrm{P}($ pendidikan ayah $=$ pendidikan dasar $\mathrm{y}=$ rendah $)=12 / 15$

$\mathrm{P}($ pekerjaan ayah $=$ petani $\mid \mathrm{y}=$ tinggi $)=42 / 65$

$\mathrm{P}($ pekerjaan ayah $=$ petani $\mid \mathrm{y}=\mathrm{rendah})=12 / 15$

$\mathrm{P}$ (penghasilan ayah=kurang dari 1 juta $\mid \mathrm{y}=$ tinggi $)=52 / 65$

$\mathrm{P}($ penghasilan ayah $=$ kurang dari 1 juta $\mathrm{y}=$ rendah $)=14 / 15$

$\mathrm{P}$ (pendidikan ibu=pendidikan dasar $\mid \mathrm{y}=$ tinggi $)=37 / 65$

$\mathrm{P}($ pendidikan $\mathrm{ibu}=$ pendidikan dasar $\mathrm{y}=$ rendah $)=10 / 15$

$\mathrm{P}($ pekerjaan ibu=tidak bekerja $\mid \mathrm{y}=$ tinggi $)=44 / 65$

$\mathrm{P}($ pekerjaan $\mathrm{ibu}=$ tidak bekerja $\mathrm{y}=$ rendah $)=10 / 15$

$\mathrm{P}$ (penghasilan ibu =tidak berpenghasilan $\mid y=$ ting $g i)=46 / 65$
$\mathrm{P}($ penghasilan $\mathrm{ibu}=$ tidak berpenghasilan $\mid y=$ rendah $)=10 / 15$

3. Kalikan semua variabel

$\mathrm{P}(\mathrm{Y}=$ Tinggi $) * \mathrm{P}($ jenis kelamin=laki-laki $\mid \mathrm{y}=$ tinggi $) * \mathrm{P}($ jenis tinggal=bersama orang tua $\mid \mathrm{y}=$ tinggi $) * \mathrm{P}($ asal sekolah=MTS $\mid \mathrm{y}=$ tinggi $) *$ $\mathrm{P}($ jarak rumah=lebih dari $10 \mathrm{~km} \mid \mathrm{y}=$ tinggi) $*$ $\mathrm{P}$ (pendidikan ayah=pendidikan dasar $\mathrm{y}=$ tinggi $) * \mathrm{P}($ pekerjaan $\quad$ ayah=petani $\mid \mathrm{y}=$ tinggi $) * \mathrm{P}($ penghasilan ayah=kurang dari 1 juta $\mid \mathrm{y}=$ tinggi $) * \mathrm{P}$ (pendidikan $\mathrm{ibu}=$ pendidikan dasar $\mid \mathrm{y}=$ tinggi $) * \mathrm{P}$ (pekerjaan $\mathrm{ibu}=$ tidak bekerja $\mid \mathrm{y}=$ tinggi) $* \mathrm{P}($ penghasilan $\mathrm{ibu}=$ tidak berpenghasilan $\mid \mathrm{y}=$ tinggi)

$=65 / 80 * 49 / 65 * 61 / 65 * 16 / 65 * 15 / 65 *$ $38 / 65 * 42 / 65 * 52 / 65 * 37 / 65 * 44 / 65 *$ $46 / 65=0,002690763$

$\mathrm{P}(\mathrm{Y}=$ Rendah $) * \mathrm{P}(\mathrm{jenis}$ kelamin=laki-laki $\mid \mathrm{y}=$ rendah $) * \mathrm{P}($ jenis tinggal $=$ bersama orang tua $\mid \mathrm{y}=$ rendah $) * \mathrm{P}($ asal sekolah $=$ MTS $\mathrm{y}=$ rendah $) * \mathrm{P}(\mathrm{jarak}$ rumah $=$ lebih dari $10 \mathrm{~km}$ $\mid \mathrm{y}=\mathrm{rendah}) * \mathrm{P}($ pendidikan ayah $=$ pendidikan dasar $\mid \mathrm{y}=$ rendah $) * \mathrm{P}($ pekerjaan ayah = petani $\mathrm{y}=$ rendah $) * \mathrm{P}($ penghasilan ayah $=$ kurang dari 1 juta $\mid \mathrm{y}=$ rendah $) * \mathrm{P}($ pendidikan $\mathrm{ibu}=$ pendidikan dasar $\mid \mathrm{y}=$ rendah $) * \mathrm{P}($ pekerjaan ibu $=$ tidak bekerja $\mid \mathrm{y}=$ rendah $) * \mathrm{P}($ penghasilan $\mathrm{ibu}=$ tidak berpenghasilan $\mid \mathrm{y}=$ rendah $)=15 / 80$ * 14/15*15/15*7/15*10/15*12/15* $12 / 15 * 14 / 15 * 10 / 15 * 10 / 15 *$ $10 / 15=0,009635995$

4. Bandingkan variabel tinggi dan rendah Dari penjelasan di atas dapat di lihat bahwa nilai probabilitas dari kelas $(\mathrm{P} \mid$ tinggi $)=$ 0,002690763 dan nilai probabilitas dari kelas $(\mathrm{P} \mid$ rendah $)=0,009635995$, sehingga dapat di simpulkan bahwa potensi tingkat kedisiplinan siswa yang berdasarkan kriteria tersebut masuk kedalam klasifikasi "rendah".

\section{B. Data testing yang kedua}

1. Hitung jumlah kelas atau label $\mathrm{P}(\mathrm{Y}=$ Tinggi $)=65 / 80$ “jumlah data potensi yang tinggi pada data training di bagi dengan jumlah total data training". $\mathrm{P}(\mathrm{Y}=$ Rendah $) \quad=15 / 80 \quad$ "jumlah data potensi yang rendah pada data training di bagi dengan jumlah total data training".

2. Menghitung jumlah kasus yang sama dengan class yang sama $\mathrm{P}(\mathrm{jenis}$ kelamin=laki-laki $\quad \mid y=$ tinggi $)=49 / 65$ 


\begin{abstract}
$\mathrm{P}(\mathrm{jenis}$
$\mid y=$ rendah $)=14 / 15$

tinggal=bersama

$\mid y=$ tinggi $)=61 / 65$

kelamin=laki-laki

$\mathrm{P}$ (jenis

orang tua

bersama orang tua $\mid y=$ rendah $)=15 / 15$

$\mathrm{P}$ (asal sekolah=SMP NEGERI

$\mid \mathrm{y}=$ tinggi $)=37 / 65 \mathrm{P}($ asal sekolah $=\mathrm{SMP}$

NEGERI $\mid y=$ rendah $)=3 / 15 \quad P($ jarak

rumah=lebih dari $10 \quad \mathrm{~km}$

$\mid \mathrm{y}=$ tinggi $)=15 / 65 \mathrm{P}($ jarak rumah $=$ lebih

dari $10 \mathrm{~km} \quad \mid \mathrm{y}=$ rendah $)=10 / 15 \mathrm{P}$

(pendidikan ayah=pendidikan menengah $\mid \mathrm{y}=$ tinggi $)=17 / 65 \mathrm{P}($ pendidikan ayah = pendidikan menengah $\mid y=$ rendah $)=3 / 15$

$\mathrm{P}($ pekerjaan ayah=petani $\mid \mathrm{y}=$ tinggi $)=42 / 65$ $\mathrm{P}($ pekerjaan ayah $=$ petani $\mid \mathrm{y}=$ rendah $)=12 / 15 \quad \mathrm{P}($ penghasilan ayah=kurang dari 1 juta $\mid y=$ tinggi $)=52 / 65$ $\mathrm{P}($ penghasilan ayah $=$ kurang dari 1 juta $\mid \mathrm{y}=$ rendah $)=14 / 15 \quad \mathrm{P}($ pendidikan $\mathrm{ibu}$ $=$ pendidikan menengah $\mid \mathrm{y}=$ tinggi $)=17 / 65$ $\mathrm{P}($ pendidikan $\mathrm{ibu}=$ pendidikan menengah $\mid \mathrm{y}=$ rendah $)=4 / 15 \mathrm{P}($ pekerjaan $\mathrm{ibu}=$ petani $\mid \mathrm{y}=$ tinggi $)=15 / 65 \mathrm{P}($ pekerjaan $\mathrm{ibu}=$ petani $\mid y=$ rendah $)=5 / 15 \quad \mathrm{P}($ penghasilan ibu $=$ kurang dari 1 juta $\mid y=$ tinggi $)=18 / 65$ $\mathrm{P}($ penghasilan $\mathrm{ibu}=$ kurang dari 1 juta $\mid \mathrm{y}=$ rendah $)=5 / 15$
\end{abstract}

3. Mengalikan semua variabel tinggi dan rendah

$\mathrm{P}(\mathrm{Y}=$ Tinggi $) * \mathrm{P}($ jenis kelamin=laki-laki $\mid \mathrm{y}=$ tinggi) * (jenis tinggal=bersama orang tua $\mid \mathrm{y}=$ tinggi) $* \mathrm{P}($ asal sekolah=SMP NEGERI $\mid \mathrm{y}=$ tinggi $) \quad * \quad \mathrm{P}(\mathrm{jarak}$ rumah=lebih dari $10 \mathrm{~km}$ |y=tinggi) * $\mathrm{P}$ (pendidikan ayah=pendidikan menengah $\mid \mathrm{y}=$ tinggi $) * \mathrm{P}($ pekerjaan $\mathrm{ayah}=$ petani $\mid \mathrm{y}=$ tinggi $) * \mathrm{P}($ penghasilan ayah=kurang dari 1 juta $\mid \mathrm{y}=$ tinggi $) * \mathrm{P}($ pendidikan ibu =pendidikan menengah $\mid \mathrm{y}=$ tinggi) $*$ $\mathrm{P}($ pekerjaan ibu =petani $\mid \mathrm{y}=$ tinggi $) *$ $\mathrm{P}$ (penghasilan $\mathrm{ibu}=\mathrm{kurang}$ dari 1 juta |y=tinggi)

$=65 / 80 * 49 / 65 * 61 / 65 * 37 / 65 * 15 / 65 *$

$17 / 65 * 42 / 65 * 52 / 65 * 17 / 65 * 15 / 65 *$

$18 / 65=0,000170617$

$\mathrm{P}(\mathrm{Y}=\mathrm{Rendah}) \quad * \quad$ (jenis kelamin=laki-laki $\mid \mathrm{y}=$ rendah $) * \mathrm{P}($ jenis tinggal = bersama orang tua $\mid \mathrm{y}=$ rendah $) * \mathrm{P}($ asal sekolah $=\mathrm{SMP}$ NEGERI $\mid \mathrm{y}=$ rendah $) * \mathrm{P}($ jarak rumah $=$ lebih dari $10 \mathrm{~km} \mid \mathrm{y}=$ rendah $) * \mathrm{P}($ pendidikan ayah $=$ pendidikan menengah $\mid \mathrm{y}=$ rendah) * $\mathrm{P}($ pekerjaan ayah $=$ petani $\mid \mathrm{y}=$ rendah $) *$
$\mathrm{P}($ penghasilan ayah $=$ kurang dari 1 juta $\mathrm{y}=$ rendah $) * \mathrm{P}($ pendidikan $\mathrm{ibu}=$ pendidikan menengah $\mid \mathrm{y}=$ rendah $) * \mathrm{P}($ pekerjaan $\mathrm{ibu}=$ petani $\mid \mathrm{y}=$ rendah $) * \mathrm{P}($ penghasilan $\mathrm{ibu}=$ kurang dari 1 juta $\mid y=$ rendah)

$=15 / 80 * 14 / 15 * 15 / 15 * 3 / 15 * 10 / 15 * 3 / 15$

$* 12 / 15 * 14 / 15 * 4 / 15 * 5 / 15 * 5 / 15$

$=0,000103243$

4. Bandingkan variabel tinggi dan rendah Dari penjelasan di atas dapat di lihat bahwa nilai probabilitas dari kelas $(\mathrm{P} \mid$ tinggi $)=$ 0,000170617 dan nilai probabilitas dari kelas $(\mathrm{P} \mid$ rendah $)=0,000103243$, sehingga dapat di simpulkan bahwa potensi tingkat kedisiplinan siswa yang berdasarkan kriteria tersebut masuk kedalam klasifikasi "tinggi".

\section{Data testing yang ke tiga}

1. Hitung jumlah kelas atau label

$\mathrm{P}(\mathrm{Y}=$ Tinggi $)=65 / 80$ “jumlah data potensi yang tinggi pada data training di bagi dengan jumlah total data training".

$\mathrm{P}(\mathrm{Y}=$ Rendah $)=15 / 80$ "jumlah data potensi yang rendah pada data training di bagi dengan jumlah total data training".Menghitung jumlah kasus yang sama dengan class yang sama

$\mathrm{P}($ jenis kelamin=laki-laki $\mid \mathrm{y}=$ tinggi $)=49 / 65$

$\mathrm{P}($ jenis kelamin=laki-laki $\mid \mathrm{y}=$ rendah $)=14 / 15$

$\mathrm{P}(\mathrm{jenis}$ tinggal=bersama orang tua $\mid y=$ tinggi $)=61 / 65$

$\mathrm{P}(\mathrm{jenis}$ tinggal $=$ bersama orang tua $\mid \mathrm{y}=$ rendah $)=15 / 15$

$\mathrm{P}($ asal sekolah $=$ MTS $\mid \mathrm{y}=$ tinggi $)=16 / 65$

$\mathrm{P}($ asal sekolah $=$ MTS $\mid \mathrm{y}=$ rendah $)=7 / 15$

$\mathrm{P}($ jarak rumah $=5$ sampai $10 \mathrm{~km}$ $\mid y=$ tinggi $)=27 / 65$

$\mathrm{P}($ jarak rumah $=5$ sampai $10 \mathrm{~km}$ $\mid y=$ rendah $)=3 / 15$

$\mathrm{P}$ (pendidikan ayah=pendidikan dasar $\mid \mathrm{y}=$ tinggi $)=38 / 65$

$\mathrm{P}($ pendidikan ayah $=$ pendidikan dasar $\mid \mathrm{y}=$ rendah $)=12 / 15$

$\mathrm{P}($ pekerjaan ayah=petani $\mid \mathrm{y}=$ tinggi $)=42 / 65$

$\mathrm{P}($ pekerjaan ayah $=$ petani $\mid \mathrm{y}=$ rendah $)=12 / 15$

$\mathrm{P}$ (penghasilan ayah=kurang dari 1 juta $\mid \mathrm{y}=$ tinggi $)=52 / 65$

$\mathrm{P}($ penghasilan ayah $=$ kurang dari 1 juta $\mid \mathrm{y}=$ rendah $)=14 / 15$

$\mathrm{P}$ (pendidikan ibu=pendidikan dasar $\mid y=$ tinggi $)=37 / 65$

$\mathrm{P}($ pendidikan $\mathrm{ibu}=$ pendidikan dasar $\mid \mathrm{y}=$ rendah $)=10 / 15$ 
$\mathrm{P}($ pekerjaan ibu $=$ tidak
$\mid \mathrm{y}=$ tinggi $)=44 / 65$
$\mathrm{P}($ pekerjaan ibu $=$ tidak bekerja
$\mid \mathrm{y}=$ rendah $)=10 / 15$
$\mathrm{P}($ penghasilan ibu $=$ tidak berpenghasilan
$\mid \mathrm{y}=$ tinggi $)=46 / 65$
$\mathrm{P}($ penghasilan ibu $=$ tidak berpenghasilan
$\mid \mathrm{y}=$ rendah $)=10 / 15$

2. Mengalikan semua variabel tinggi dan rendah

$\mathrm{P}(\mathrm{Y}=$ Tinggi $) \quad * \quad \mathrm{P}($ jenis kelamin=laki-laki $\mid \mathrm{y}=$ tinggi $) * \mathrm{P}($ jenis tinggal=bersama orang tua $\mid \mathrm{y}=$ tinggi $) * \mathrm{P}($ asal sekolah=MTS $\mid \mathrm{y}=$ tinggi $) *$ $\mathrm{P}($ jarak rumah $=5$ sampai $10 \mathrm{~km} \mid \mathrm{y}=$ tinggi) * $\mathrm{P}$ (pendidikan ayah=pendidikan dasar $\mid \mathrm{y}=$ tinggi) * $\mathrm{P}($ pekerjaan ayah=petani $\mid \mathrm{y}=$ tinggi) * $\mathrm{P}$ (penghasilan ayah=kurang dari 1 juta $\mid \mathrm{y}=$ tinggi) * $\mathrm{P}$ (pendidikan $\mathrm{ibu}=$ pendidikan dasar $\mid \mathrm{y}=$ tinggi $) * \mathrm{P}$ (pekerjaan $\mathrm{ibu}=$ tidak bekerja $\mid \mathrm{y}=$ tinggi $) * \mathrm{P}($ penghasilan $\mathrm{ibu}=$ tidak berpenghasilan $\mid \mathrm{y}=$ tinggi)

$=65 / 80 * 49 / 65 * 61 / 65 * 16 / 65 * 27 / 65 *$

$38 / 65 * 42 / 65 * 52 / 65 * 37 / 65 * 44 / 65 *$ $46 / 65=0,004843373$

$\mathrm{P}(\mathrm{Y}=$ Rendah $) \quad * \quad \mathrm{P}(\mathrm{jenis}$ kelamin=laki-laki $\mathrm{y}=$ rendah $) * \mathrm{P}($ jenis tinggal $=$ bersama orang tua $\mid \mathrm{y}=$ rendah $) * \mathrm{P}($ asal sekolah $=$ MTS $\mathrm{y}=$ rendah $) * \mathrm{P}(\mathrm{jarak}$ rumah $=5$ sampai $10 \mathrm{~km}$ $\mathrm{y}=$ rendah $) * \mathrm{P}$ (pendidikan ayah $=$ pendidikan dasar $\mid \mathrm{y}=$ rendah $) * \mathrm{P}($ pekerjaan ayah = petani $\mathrm{y}=$ rendah $) * \mathrm{P}($ penghasilan ayah $=$ kurang dari 1 juta $\mid \mathrm{y}=$ rendah $) * \mathrm{P}$ (pendidikan $\mathrm{ibu}=$ pendidikan dasar $\mid \mathrm{y}=$ rendah $) * \mathrm{P}($ pekerjaan ibu $=$ tidak bekerja $\mid \mathrm{y}=$ rendah $) * \mathrm{P}($ penghasilan $\mathrm{ibu}$ $=$ tidak berpenghasilan $\mid \mathrm{y}=$ rendah)

$=15 / 80 * 14 / 15 * 15 / 15 * 7 / 15 * 3 / 15 * 12 / 15 *$ $12 / 15 * 14 / 15 * 10 / 15 * 10 / 15 *$ $10 / 15=0,002890798$

\section{Bandingkan variabel tinggi dan rendah}

Dari penjelasan di atas dapat di lihat bahwa nilai probabilitas dari kelas $(\mathrm{P} \mid$ tinggi $)=$ 0,004843373 dan nilai probabilitas dari kelas $(\mathrm{P} \mid$ rendah $)=0,002890798$, sehingga dapat di simpulkan bahwa potensi tingkat kedisiplinan siswa yang berdasarkan kriteria tersebut masuk kedalam klasifikasi "tinggi”.

\section{Data testing ke empat}

1. Hitung jumlah kelas atau label
$\mathrm{P}(\mathrm{Y}=$ Tinggi $)=65 / 80$ “jumlah data potensi yang tinggi pada data training di bagi dengan jumlah total data training".

$\mathrm{P}(\mathrm{Y}=$ Rendah $)=15 / 80$ "jumlah data potensi yang rendah pada data training di bagi dengan jumlah total data training".

2. Menghitung jumlah kasus yang sama dengan class yang sama

$\mathrm{P}($ jenis kelamin=laki-laki $\mid \mathrm{y}=$ tinggi $)=49 / 65$

$\mathrm{P}($ jenis kelamin=laki-laki $\mid \mathrm{y}=$ rendah $)=14 / 15$

$\mathrm{P}(\mathrm{jenis}$ tinggal=bersama orang tua $\mid y=$ tinggi $)=61 / 65$

$\mathrm{P}(\mathrm{jenis}$ tinggal $=$ bersama orang tua $\mid y=$ rendah $)=15 / 15$

$\mathrm{P}($ asal sekolah $=$ SMP NEGERI $\mid \mathrm{y}=$ tinggi $)=37 / 65$

$\mathrm{P}($ asal sekolah $=\mathrm{SMP}$ NEGERI $\mid \mathrm{y}=$ rendah $)=3 / 15$

$\mathrm{P}($ jarak rumah $=5$ sampai $10 \mathrm{~km} \mid \mathrm{y}=$ tinggi $)=27 / 65$

$\mathrm{P}($ jarak rumah $=5$ sampai $10 \mathrm{~km} \mid \mathrm{y}=$ rendah $)=3 / 15$

$\mathrm{P}$ (pendidikan ayah=pendidikan dasar

|y=tinggi $)=38 / 65$

$\mathrm{P}($ pendidikan ayah $=$ pendidikan dasar $\mid \mathrm{y}=$ rendah $)=12 / 15$

$\mathrm{P}($ pekerjaan ayah=buruh $\mid \mathrm{y}=$ tinggi $)=10 / 65$

$\mathrm{P}($ pekerjaan ayah $=$ buruh $\mid \mathrm{y}=$ rendah $)=1 / 15$

$\mathrm{P}$ (penghasilan ayah=kurang dari 1 juta $\mid \mathrm{y}=$ tinggi $)=52 / 65$

$\mathrm{P}($ penghasilan ayah $=$ kurang dari 1 juta $\mid y=$ rendah $)=14 / 15$

$\mathrm{P}$ (pendidikan ibu=pendidikan dasar |y=tinggi $)=37 / 65$

$\mathrm{P}($ pendidikan $\mathrm{ibu}=$ pendidikan dasar $\mid y=$ rendah $)=10 / 15$

$\mathrm{P}($ pekerjaan ibu =tidak bekerja

|y=tinggi $)=44 / 65$

$\mathrm{P}($ pekerjaan ibu $=$ tidak bekerja

$\mid y=$ rendah $)=10 / 15$

$\mathrm{P}($ penghasilan $\mathrm{ibu}=$ tidak berpenghasilan $\mid y=$ tinggi $)=46 / 65$

$\mathrm{P}($ penghasilan $\mathrm{ibu}=$ tidak berpenghasilan $\mid y=$ rendah $)=10 / 15$

3. Mengalikan semua variabel tinggi dan rendah

$\mathrm{P}(\mathrm{Y}=$ Tinggi $) \quad * \quad \mathrm{P}($ jenis $\quad$ kelamin=laki-laki $\mid \mathrm{y}=$ tinggi $) * \mathrm{P}($ jenis tinggal=bersama orang tua $\mid \mathrm{y}=$ tinggi $) * \mathrm{P}$ (asal sekolah=SMP NEGERI $\mid \mathrm{y}=$ tinggi $) * \mathrm{P}($ jarak rumah $=5$ sampai $10 \mathrm{~km}$ $\mid \mathrm{y}=$ tinggi) $* \mathrm{P}$ (pendidikan ayah=pendidikan dasar $\mid \mathrm{y}=$ tinggi) * $\mathrm{P}($ pekerjaan ayah=buruh $\mid \mathrm{y}=$ tinggi $) * \mathrm{P}($ penghasilan ayah=kurang dari 1 juta $\mid \mathrm{y}=$ tinggi $) * \mathrm{P}($ pendidikan $\mathrm{ibu}=$ pendidikan dasar $\mid \mathrm{y}=$ tinggi $) * \mathrm{P}($ pekerjaan $\mathrm{ibu}=$ tidak 
bekerja $\mid \mathrm{y}=$ tinggi $) * \mathrm{P}($ penghasilan $\mathrm{ibu}=$ tidak berpenghasilan $\mid \mathrm{y}=$ tinggi)

$=65 / 80 * 49 / 65 * 61 / 65 * 37 / 65 * 27 / 65 *$

$38 / 65 * 10 / 65 * 52 / 65 * 37 / 65 * 44 / 65 *$ 46/65=0,002666738

$\mathrm{P}(\mathrm{Y}=$ Rendah $) \quad * \quad \mathrm{P}($ jenis $\quad$ kelamin=laki-laki $\mathrm{y}=$ rendah $) * \mathrm{P}($ jenis tinggal $=$ bersama orang tua $\mid \mathrm{y}=$ rendah $) * \mathrm{P}($ asal sekolah $=\mathrm{SMP}$ NEGERI $\mid \mathrm{y}=$ rendah $) * \mathrm{P}($ jarak rumah $=5$ sampai $10 \mathrm{~km} \mid \mathrm{y}=$ rendah $) * \mathrm{P}($ pendidikan ayah $=$ pendidikan dasar $\mid \mathrm{y}=$ rendah $)$

$\mathrm{P}($ pekerjaan ayah = buruh $\mid \mathrm{y}=$ rendah $) *$ $\mathrm{P}($ penghasilan ayah $=$ kurang dari 1 juta $\mathrm{y}=$ rendah $) * \mathrm{P}($ pendidikan $\mathrm{ibu}=$ pendidikan dasar $\mid \mathrm{y}=$ rendah $) * \mathrm{P}($ pekerjaan $\mathrm{ibu}=$ tidak bekerja $\mid \mathrm{y}=$ rendah $) * \mathrm{P}($ penghasilan $\mathrm{ibu}=$ tidak berpenghasilan $\mid \mathrm{y}=$ rendah)

$=15 / 80 * 14 / 15 * 15 / 15 * 3 / 15 * 3 / 15 * 12 / 15 *$

$1 / 15 * 14 / 15 * 10 / 15 * 10 / 15 * 10 / 15$

$=0,000103243$

4. Bandingkan variabel tinggi dan rendah Dari penjelasan di atas dapat di lihat bahwa nilai probabilitas dari kelas $(\mathrm{P} \mid$ tinggi $)=$ 0,002666738 dan nilai probabilitas dari kelas $(\mathrm{P} \mid$ rendah $)=0,000103243$, sehingga dapat di simpulkan bahwa potensi tingkat kedisiplinan siswa yang berdasarkan kriteria tersebut masuk kedalam klasifikasi "tinggi".

\section{E. Data testing ke lima}

1. Hitung jumlah kelas atau label

$\mathrm{P}(\mathrm{Y}=$ Tinggi $)=65 / 80$ “ jumlah data potensi yang tinggi pada data training di bagi dengan jumlah total data training".

$\mathrm{P}(\mathrm{Y}=$ Rendah $)=15 / 80$ "jumlah data potensi yang rendah pada data training di bagi dengan jumlah total data training".

2. Menghitung jumlah kasus yang sama dengan class yang sama

$\mathrm{P}($ jenis kelamin=laki-laki $\mid \mathrm{y}=$ tinggi $)=49 / 65 \mathrm{P}($ jenis kelamin=laki-laki $\quad \mid \mathrm{y}=$ rendah $)=14 / 15 \quad \mathrm{P}($ jenis tinggal=bersama orang tua $\mid y=$ tinggi $)=61 / 65$ $\mathrm{P}(\mathrm{jenis}$ tinggal $=$ bersama orang tua $\mid \mathrm{y}=$ rendah $)=15 / 15 \mathrm{P}($ asal sekolah=SMP SWASTA $\mid \mathrm{y}=$ tinggi $)=12 / 65 \mathrm{P}($ asal sekolah $=\mathrm{SMP}$ SWASTA $\mid \mathrm{y}=\mathrm{rendah})=5 / 15 \mathrm{P}(\mathrm{jarak}$ rumah=5 sampai $10 \mathrm{~km}$ y=tinggi $)=27 / 65 \mathrm{P}($ jarak rumah $=5$ sampai $10 \mathrm{~km}$ $\mid \mathrm{y}=$ rendah $)=3 / 15 \quad \mathrm{P}($ pendidikan ayah=pendidikan dasar $\mid \mathrm{y}=$ tinggi $)=38 / 65 \quad \mathrm{P}($ pendidikan ayah = pendidikan dasar $\mid \mathrm{y}=$ rendah $)=12 / 15 \quad \mathrm{P}($ pekerjaan ayah=petani $\mid \mathrm{y}=$ tinggi $)=42 / 65 \mathrm{P}($ pekerjaan ayah $=$ petani $\quad \mid \mathrm{y}=$ rendah $)=12 / 15 \quad \mathrm{P}($ penghasilan ayah=kurang dari 1 juta $\mid y=$ tinggi $)=52 / 65$

$\mathrm{P}($ penghasilan ayah $=$ kurang dari 1 juta $\mid y=$ rendah $)=14 / 15$

$\mathrm{P}$ (pendidikan ibu =pendidikan menengah |y=tinggi $)=17 / 65$

$\mathrm{P}$ (pendidikan $\mathrm{ibu}=$ pendidikan menengah $\mid \mathrm{y}=$ rendah $)=4 / 15$

$\mathrm{P}($ pekerjaan $\mathrm{ibu}=$ tidak bekerja $\mid \mathrm{y}=$ tinggi $)=44 / 65$

$\mathrm{P}($ pekerjaan $\mathrm{ibu}=$ tidak bekerja $\mid \mathrm{y}=$ rendah $)=10 / 15$

$\mathrm{P}$ (penghasilan ibu =tidak berpenghasilan $\mid y=$ tinggi $)=46 / 65$

$\mathrm{P}($ penghasilan $\mathrm{ibu}=$ tidak berpenghasilan $\mid y=$ rendah $)=10 / 15$

3. Mengalikan semua variabel tinggi dan rendah

$\mathrm{P}(\mathrm{Y}=$ Tinggi $) * \mathrm{P}($ jenis kelamin=laki-laki $\mid \mathrm{y}=$ tinggi $)$ * $\mathrm{P}$ (jenis tinggal=bersama orang tua $\mid \mathrm{y}=$ tinggi $)^{*}$ $\mathrm{P}$ (asal sekolah=SMP SWASTA |y=tinggi) * $\mathrm{P}($ jarak rumah=5 sampai $10 \mathrm{~km}$ |y=tinggi) * $\mathrm{P}$ (pendidikan ayah=pendidikan dasar $\mid \mathrm{y}=$ tinggi $) *$ $\mathrm{P}($ pekerjaan ayah=petani $\quad \mid \mathrm{y}=$ tinggi $) \quad *$ $\mathrm{P}$ (penghasilan ayah=kurang dari 1 juta $\mid \mathrm{y}=$ tinggi $) *$ $\mathrm{P}$ (pendidikan $\mathrm{ibu}=$ pendidikan menengah |y=tinggi) *

$\mathrm{P}($ pekerjaan ibu =tidak bekerja $\mid \mathrm{y}=$ tinggi $) *$ $\mathrm{P}$ (penghasilan $\mathrm{ibu}=$ tidak berpenghasilan $\mid \mathrm{y}=$ tinggi) $=65 / 80 * 49 / 65 * 61 / 65 * 12 / 65 * 27 / 65 * 38 / 65 *$ $42 / 65 * 52 / 65 * 17 / 65 * 44 / 65 * 46 / 65=0,001669$

$\mathrm{P}(\mathrm{Y}=$ Rendah $) \quad * \quad \mathrm{P}($ jenis $\quad$ kelamin=laki-laki $\mid \mathrm{y}=$ rendah $) * \mathrm{P}($ jenis tinggal $=$ bersama orang tua $\mathrm{y}=$ rendah $) * \mathrm{P}($ asal sekolah $=\mathrm{SMP}$ SWASTA $\mid \mathrm{y}=$ rendah $) * \mathrm{P}(\mathrm{jarak}$ rumah $=5$ sampai $10 \mathrm{~km}$ $\mathrm{y}=$ rendah $) * \mathrm{P}($ pendidikan ayah $=$ pendidikan dasar $\mid \mathrm{y}=$ rendah $) * \mathrm{P}($ pekerjaan ayah $=$ petani $\mathrm{y}=$ rendah $) * \mathrm{P}($ penghasilan ayah $=$ kurang dari 1 juta $\mid \mathrm{y}=$ rendah $) * \mathrm{P}($ pendidikan $\mathrm{ibu}=$ pendidikan menengah $\mid \mathrm{y}=$ rendah $) * \mathrm{P}($ pekerjaan $\mathrm{ibu}=$ tidak bekerja $\mid \mathrm{y}=$ rendah $) * \mathrm{P}($ penghasilan $\mathrm{ibu}=$ tidak berpenghasilan $\mid \mathrm{y}=$ rendah)

$=15 / 80 * 14 / 15 * 15 / 15 * 5 / 15 * 3 / 15 * 12 / 15 *$ $12 / 15 * 14 / 15 * 4 / 15 * * 10 / 15 \quad *$ $10 / 15=0,000825942$

\section{Bandingkan variabel tinggi dan rendah}

Dari penjelasan di atas dapat di lihat bahwa nilai probabilitas dari kelas $(\mathrm{P} \mid$ tinggi $)=$ 0,001669 dan nilai probabilitas dari kelas $(\mathrm{P}$ | rendah $)=0,000825942$, sehingga dapat di simpulkan bahwa potensi tingkat kedisiplinan siswa yang berdasarkan kriteria tersebut masuk kedalam klasifikasi "tinggi”. 
Penghitungan data sampai dengan 8 testing sehingga dapat simpulkan seperti pada tabel dibawah ini :

\section{a. Kesimpulan Data Testing}

Tabel 2. Kesimpulan Data Testing

\begin{tabular}{|c|c|c|c|c|}
\hline $\begin{array}{l}\mathrm{N} \\
\mathrm{O}\end{array}$ & Nama & $\begin{array}{c}\text { Tingkat } \\
\text { kedisipli } \\
\text { nan }\end{array}$ & $\begin{array}{c}\text { Class } \\
\text { prediks } \\
\mathrm{i} \\
\end{array}$ & $\begin{array}{c}\text { Nilai } \\
\text { probabili } \\
\text { tas }\end{array}$ \\
\hline 1. & $\begin{array}{l}\text { Ade tia } \\
\text { saputra }\end{array}$ & rendah & $\begin{array}{l}\text { renda } \\
\mathrm{h}\end{array}$ & $\begin{array}{l}0,009635 \\
9945130 \\
3157\end{array}$ \\
\hline 2. & $\begin{array}{l}\text { Adi } \\
\text { ngaliman }\end{array}$ & tinggi & tinggi & $\begin{array}{l}0,000170 \\
6172518 \\
0400\end{array}$ \\
\hline 3. & $\begin{array}{l}\text { Adi } \\
\text { pratama }\end{array}$ & rendah & tinggi & $\begin{array}{l}0,004843 \\
3731287 \\
6573\end{array}$ \\
\hline 4. & $\begin{array}{l}\text { Adi } \\
\text { saputra }\end{array}$ & tinggi & tinggi & $\begin{array}{l}0,002666 \\
7381810 \\
1685\end{array}$ \\
\hline 5. & $\begin{array}{l}\text { Adi tiya } \\
\text { alvaro }\end{array}$ & rendah & tinggi & $\begin{array}{l}0,001669 \\
0001997 \\
7739\end{array}$ \\
\hline 6. & $\begin{array}{l}\text { Agung } \\
\text { pratama }\end{array}$ & tinggi & tinggi & $\begin{array}{l}0,004383 \\
7011420 \\
0789 \\
\end{array}$ \\
\hline 7. & $\begin{array}{l}\text { Agus } \\
\text { lilik } \\
\text { hermawa } \\
\text { n }\end{array}$ & tinggi & tinggi & $\begin{array}{l}0,011200 \\
3003602 \\
708\end{array}$ \\
\hline 8. & $\begin{array}{l}\text { Agus } \\
\text { saputra }\end{array}$ & rendah & tinggi & $\begin{array}{l}0,000107 \\
3625859 \\
5059\end{array}$ \\
\hline
\end{tabular}

Dari kesimpulan tabel hasil data testing di atas dengan menggunakan 8 sampel data testing, maka selanjutnya yaitu mencari penyimpangan data. Berikut ini tabel hasil penyimpangan data sebagai berikut:

Tabel 3. Hasil Pencarian Penyimpangan Data

\begin{tabular}{|l|l|}
\hline \multicolumn{2}{|c|}{ hasil } \\
\hline Mean & 0,004334636 \\
\hline Standard Error & 0,001467501 \\
\hline Median & 0,00352522 \\
\hline Mode & \#N/A \\
\hline Standard Deviation & 0,00415072 \\
\hline Sample Variance & $1,72285 \mathrm{E}-05$ \\
\hline Kurtosis & $-0,637618707$ \\
\hline
\end{tabular}

\begin{tabular}{|l|l|}
\hline Skewness & 0,802893419 \\
\hline Range & 0,011092938 \\
\hline Minimum & 0,000107363 \\
\hline Maximum & 0,0112003 \\
\hline Sum & 0,034677087 \\
\hline Count & 8 \\
\hline $\begin{array}{l}\text { Confidence } \\
\text { Level }(95,0 \%)\end{array}$ & 0,003470089 \\
\hline
\end{tabular}

Dari kesimpulan tabel hasil pencarian penyimpangan data maka di dapat nilai mean 0,004334636, nilai Variance (s2) 1,72285E-05, nilai Standart deviasi 0,00415072, nilai Standart eror 0,001467501. Dari hasil nilai standar eror di atas maka dapat di cari estimasi eror dari hasil data testing tersebut. Berikut ini pencarian estimasi eror pada hasil data testing sebagai berikut:

Tabel 4. Pencarian Nilai Eror

\begin{tabular}{|c|l|l|l|}
\hline $\mathrm{n}$ & $\mathrm{n}$ & $\begin{array}{l}\text { Hasil } \\
\text { pengklasifikasian }\end{array}$ & Nilai eror \\
\hline 1 & $\begin{array}{l}\text { Ade tia } \\
\text { saputra }\end{array}$ & $\begin{array}{l}0,0096359945130 \\
3157\end{array}$ & $\begin{array}{l}0,001439 \\
397\end{array}$ \\
\hline 2 & $\begin{array}{l}\text { Adi } \\
\text { ngalima } \\
\mathrm{n}\end{array}$ & $\begin{array}{l}0,0001706172518 \\
04006\end{array}$ & $\begin{array}{l}0,001450 \\
162\end{array}$ \\
\hline 3 & $\begin{array}{l}\text { Adi } \\
\text { pratama }\end{array}$ & $\begin{array}{l}0,0048433731287 \\
6573\end{array}$ & $\begin{array}{l}0,001467 \\
242\end{array}$ \\
\hline 4 & $\begin{array}{l}\text { Adi } \\
\text { saputra }\end{array}$ & $\begin{array}{l}0,0026667381810 \\
1685\end{array}$ & $\begin{array}{l}0,001464 \\
719\end{array}$ \\
\hline 5 & $\begin{array}{l}\text { Adi tiya } \\
\text { alvaro }\end{array}$ & 0,0016690001997 & 0,001460 \\
7739 & 396 \\
\hline 6 & $\begin{array}{l}\text { Agung } \\
\text { pratama }\end{array}$ & 0,0043837011420 & 0,001467 \\
0789 & 499 \\
\hline 7 & $\begin{array}{l}\text { Agus } \\
\text { lilik } \\
\text { hermaw } \\
\text { an }\end{array}$ & $\begin{array}{l}0,0112003003602 \\
708\end{array}$ & $\begin{array}{l}0,001420 \\
364\end{array}$ \\
\hline 8 & $\begin{array}{l}\text { Agus } \\
\text { saputra }\end{array}$ & $\begin{array}{l}0,0001073625859 \\
50592\end{array}$ & $\begin{array}{l}0,001449 \\
631\end{array}$ \\
\hline
\end{tabular}

Tabel 5. Perangkingan Berdasarkan Nilai Eror

\begin{tabular}{|l|l|l|l|}
\hline No & Nama & $\begin{array}{l}\text { Hasil } \\
\text { pengklasifikasia } \\
\mathrm{n}\end{array}$ & Nilai eror \\
\hline 1 & $\begin{array}{l}\text { Agung } \\
\text { pratama }\end{array}$ & $\begin{array}{l}0,00438370114 \\
200789\end{array}$ & $\begin{array}{l}0,001467 \\
499\end{array}$ \\
\hline 2 & $\begin{array}{l}\text { Adi } \\
\text { pratama }\end{array}$ & $\begin{array}{l}0,00484337312 \\
876573\end{array}$ & $\begin{array}{l}0,001467 \\
242\end{array}$ \\
\hline 3 & Adi & 0,00266673818 & 0,001464 \\
\hline
\end{tabular}




\begin{tabular}{|l|l|l|l|}
\hline & saputra & 101685 & 719 \\
\hline 4 & $\begin{array}{l}\text { Adi tiya } \\
\text { alvaro }\end{array}$ & 0,00166900019 & 0,001460 \\
977739 & 396 \\
\hline 5 & $\begin{array}{l}\text { Adi } \\
\text { ngaliman }\end{array}$ & 0,00017061725 & 0,001450 \\
1804006 & 162 \\
\hline 6 & $\begin{array}{l}\text { Agus } \\
\text { saputra }\end{array}$ & $\begin{array}{l}0,00010736258 \\
5950592\end{array}$ & 0,001449 \\
631 \\
\hline 7 & $\begin{array}{l}\text { Ade tia } \\
\text { saputra }\end{array}$ & 0,00963599451 & 0,001439 \\
& 303157 & 397 \\
8 & $\begin{array}{l}\text { Agus } \\
\text { lilik } \\
\text { hermawa } \\
\text { n }\end{array}$ & 0,01120030036 & 0,001420 \\
& 02708 & 364 \\
\hline
\end{tabular}

\section{b. Akurasi data testing}

Dari hasil kesimpulan hitung data training di atas, maka selanjutnya adalah melakukan penghitungan keakuratan sebagai uji coba seberapa besarkah kehandalan sebuah algoritma tersebut. Maka pehitungan dapat di lakukan dengan formula sebagai berikut:

\section{Akurasi}

kebenaran $=$ total data hasil prediksi yang benar jumlah prediksi yang di lakukan $X \mathbf{1 0 0 \%}$ Akurasi

kesalahan $=\frac{\text { total data hasil prediksi yang salah }}{\text { jumlah prediksi yang di lakukan }} \times 100 \%$ Tabel 6. Confusion Tabel

\begin{tabular}{|c|c|c|}
\hline & \multicolumn{2}{|c|}{ class } \\
\hline prediksi & tinggi & rendah \\
\hline tinggi & 4 & 3 \\
\hline rendah & 0 & 1 \\
\hline
\end{tabular}

Akurasi

kebenaran $=(4+1) /(4+3+0+1) * 100 \%=63 \%$ Akurasi

kesalahan $=(0+3) /(4+3+0+1) * 100 \%=38 \%$

Dari hitungan di atas, dapat di simpulkan bahwa hasil perhitungan akurasi dan juga kesalahan pada data testing yang berjumlah 8 data, memiliki keakuratan sebesar 63\% data yang benar dan $38 \%$ data yang eror. Dimana pada class tinggi memiliki jumlah 7 data, di identifikasi yang benar sebanyak 4 data dan di identifikasi yang salah sebanyak 3 data. Selain itu class rendah memiliki jumlah data sebanyak 1 data, di antaranya yaitu 0 data di indetifikasi benar, dan 1 data di identifikasi salah.

\begin{tabular}{|l|l|}
\hline Guru BK & Kepala Sekolah \\
\hline
\end{tabular}

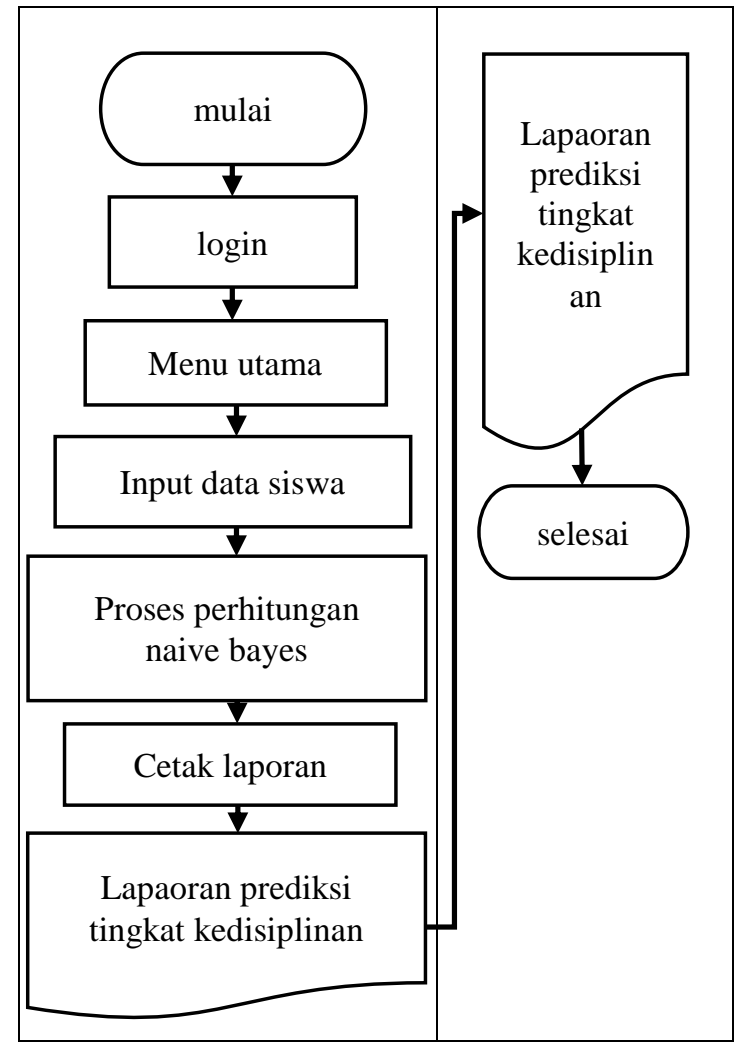

Gambar 1. Flowchart Sistem Yang Di Usulkan

\section{HASIL DAN PEMBAHASAN}

\subsection{Menu login}

Menu login merupakan menu yang pertama kali muncul ketika aplikasi di jalankan, menu ini di lengkapi dengan jam dan tanggal yang update. Menu ini memiliki beberapa komponen diantaranya yaitu:

1) Kolom ke 1 di gunakan untuk memasukan username.

2) Kolom ke 2 di gunakan untuk memasukan password.

3) Tombol masuk berfungsi untuk proses pengverifikasian username dan password yang sebelumnya telah di inputkan di kolom.

4) Tombol batal di gunakan untuk membatalkan proses login dan untuk menutup aplikasi.

Untuk menjalankan aplikasi ini cukup dengan menekan icon WindowsApplication3 - Shortcut di pc, maka aplikasi ini akan berjalan dan menu login akan tampil. Setelah itu masukan username dan password yang sesuai atau benar dengan menekan tombol masuk untuk menerima hak akses ke menu utama. Tampilan menu login dapat dilihat pada gambar 2 di bawah ini. 


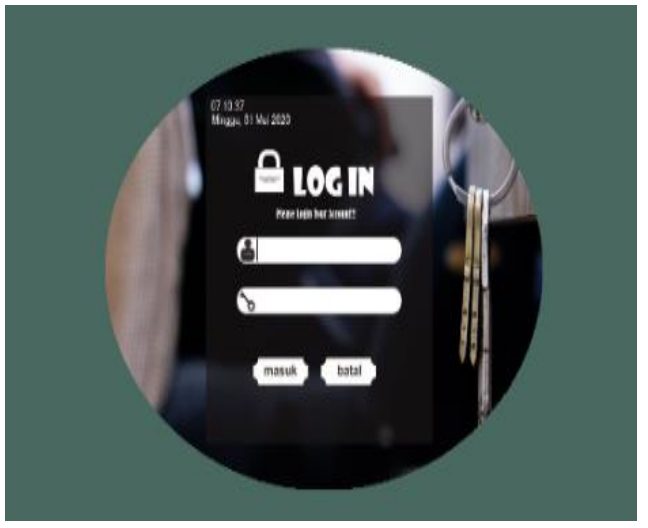

Gambar 2. Menu Login

\subsection{Menu utama}

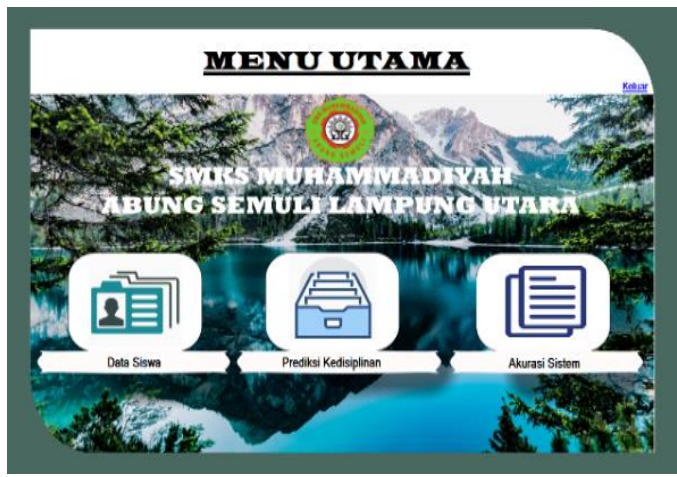

Gambar 3. Menu Utama

Menu utama merupakan menu yang akan tampil setelah proses login di lakukan dengan benar. Menu ini memiliki beberapa komponen yang dapat di akses di antaranya yaitu:

1) Tombol data siswa, tombol ini di gunakan untuk memasuki form menu data siswa.

2) Tombol prediksi kedisiplinan merupakan tombol yang di gunakan untuk memasuki form menu prediksi kedisiplinan.

3) Tombol akurasi system merupakan tombol yang di gunakan untuk mememasuki form akurasi system.

4) Tombol keluar merupakan tombol yang di gunakan untuk menutup atau mengakhiri seluruh aplikasi yang berjalan.

Untuk menjalankan menu utama ini cukup dengan verifikasi yang benar di menu login maka menu utama ini akan tampil. Untuk menutup tampilan ini cukup mengeklik tombol keluar yang ada di pojok kanan atas. Berikut ini gambar menu utama dapat di lihat pada gambar di bawah ini.

\subsection{Menu Data Siswa}

menu data siswa merupakan menu yang berfungsi untuk proses penginputan data siswa. Menu ini memilki beberapa komponen diantaranya yaitu:

1) 12 kolom yang di gunakan untuk memasukan data siswa sesuai dengan nama variable masing-masing.

2) Tombol tambah merupakan tombol yang di gunakan untuk menyimpan hasil inputan pada kolom yang sudah di isi.

3) Tombol edit merupakan tombol yang di gunakan untuk perubahan data inputan yang salah.

4) Tombol delete merupakan tombol yang di gunakan untuk menghapus data berdasarkan id nya.

5) Tombol print merupakan tombol yang di gunakan untuk mencetak hasil inputan data siswa yang di jadikan sebagai data training atau data uji coba.

6) Tombol truncate merupakan tombol yang di gunakan untuk menghapus semua atau mengkosongkan penyimpanan data siswa.

7) Tombol import excel merupakan tombol yang di gunakan untuk menginport data excel. Berikut ini tampilan menu data siswa dapat di lihat pada gambar di bawah ini.

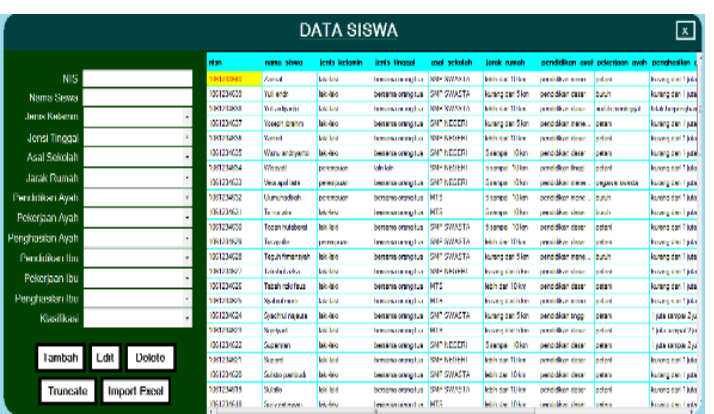

Gambar 2. Menu Data Siswa

\subsection{Menu Prediksi Kedisiplinan (formulir 1)}

Menu prediksi kedisiplinan (formulir 1) merupakan menu yang di manfaatkan untuk proses penginputan data testing serta proses pengklasifikasian. Menu ini memiliki beberapa komponen di antaranya yaitu:

1) 11 kolom inputan yang di gunakan untuk menginputkan data sesuai variable masingmasing.

2) Tombol prediksi merupakan tombol yang di manfaatkan untuk proses pengklasifikasian yang 
berdasarkan inputan pada kolom serta menyimpan hasil prediksi.

3) Tombol edit merupakan tombol yang di gunakan untuk mengedit inputan data yang salah serta menghitung ulang proses pengklasifikasian berdasarkan variable inputan yang di edit.

4) Tombol delete merupakan tombol yang di gunakan untuk proses penghapusan data hasil prediksi berdasarkan id.

5) Tombol truncate merupakan tombol yang digunakan untuk penghapusan seluruh data hasil prediksi.

6) Tombol print merupakan tombol yang di gunakan untuk mencetak hasil prediksi.

7) Tombol pilih file merupakan tombol yang di gunakan untuk mencari file excel dan menginport data excel.

8) Tombol hapus colums merupakan tombol yang di gunakan untuk mengkosongkan seluruh kolom yang terdapat pada form.

Untuk menjalankan Menu Prediksi Kedisiplinan (formulir 1) ini, terlebih dahulu user masuk kedalam menu utama aplikasi dan kemudian pilih Menu Prediksi Kedisiplinan kemudian pilih menu formulir

Gambar 3. Menu Cek Hitungan

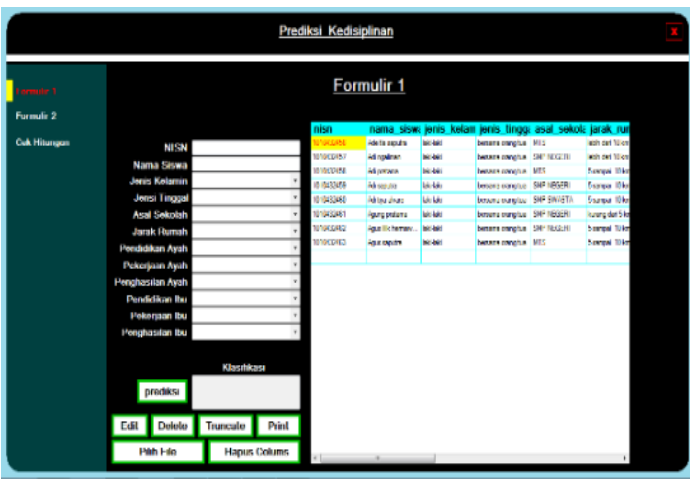

Gambar 5. Menu Prediksi Kedisiplinan (formulir 1)

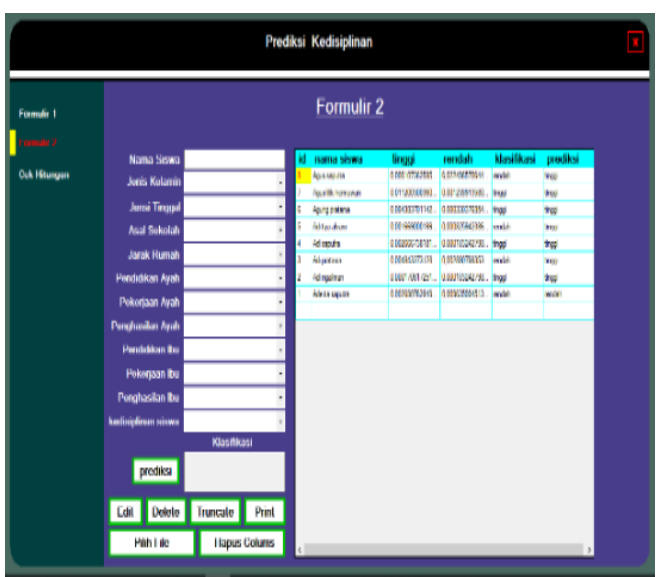

Gambar 6. Menu Prediksi Kedisiplinan

\subsection{Menu Prediksi Kedisiplinan (formulir 2)}

Menu prediksi kedisiplinan (formulir 2) merupakan menu yang di manfaatkan sebagai proses penginputan data testing serta proses pengklasifikasian. Menu ini memiliki beberapa komponen di antaranya yaitu:

1) 12 kolom inputan yang di gunakan untuk menginputkan data sesuai variable masingmasing.

2) Tombol prediksi merupakan tombol yang di manfaatkan sebagai proses pengklasifikasian yang berdasarkan inputan pada kolom serta menyimpan hasil prediksi.

3) Tombol edit merupakan tombol yang di gunakan untuk mengedit inputan data yang salah serta menghitung ulang proses pengklasifikasian berdasarkan variable inputan yang di edit.

4) Tombol delete merupakan tombol yang di manfaatkan sebagai proses penghapusan data hasil prediksi berdasarkan id.

5) Tombol truncate merupakan tombol yang digunakan untuk penghapusan seluruh data hasil prediksi.

6) Tombol print merupakan tombol yang di gunakan untuk mencetak hasil prediksi.

7) Tombol pilih file merupakan tombol yang di gunakan untuk mencari file excel dan menginport data excel.

8) Tombol hapus colums merupakan tombol yang di gunakan untuk mengkosongkan seluruh kolom yang terdapat pada form.

\subsection{Menu Cek Hitungan}

menu cek hitungan merupakan menu yang di gunakan untuk mengecek hasil hitungan dari formulir 1 dan formulir 2. Menu ini hanya terdiri dari 94 kolom inputan dan label berdasarkan hasil. Untuk menjalankan menu cek hitungan ini, terlebih dahulu user masuk kedalam menu utama aplikasi dan kemudian pilih Menu Prediksi Kedisiplinankemudian pilih menu cek hitungan.

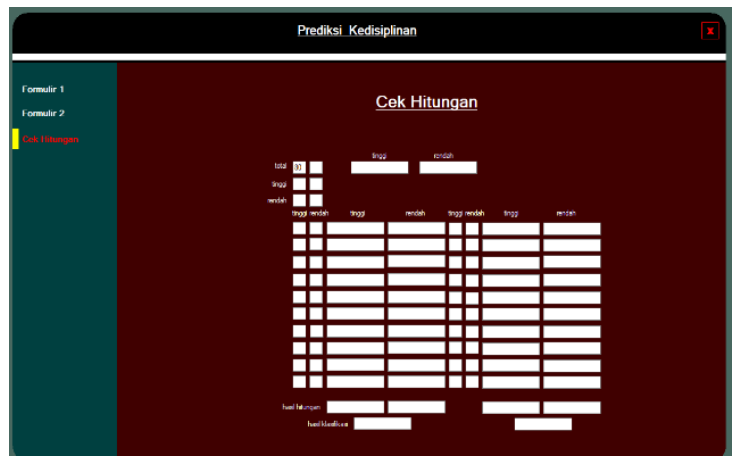




\subsection{Menu Cek Akurasi system}

Menu akurasi system merupakan menu yang di gunakan hanya untuk menampilkan dan mengecek tingkat akurasi hasil prediksi serta mengecek hasil tingkat eror hasil pediksi.

Menu akurasi system ini memiliki beberapa komponen diantaranya yaitu:

1) Tombol testing merupakan tombol yang di gunakan untuk menghitung nilai klas dan menampilkannya pada table prediksi.

2) Tombol hitung merupakan tombol yang di gunakan untuk menghitung serta menampilkan hasil hitungan akurasi dan error hasil prediksi.

3) Terdapat 2 tabel sebagai informasi dari hasil testing.

Untuk menjalankan menu akurasi system ini, terlebih dahulu masuk ke menu utama kemudian pilih menu akurasi system, maka menu akurasi system akan tampil.

\subsection{Menu Laporan Hasil Prediksi}

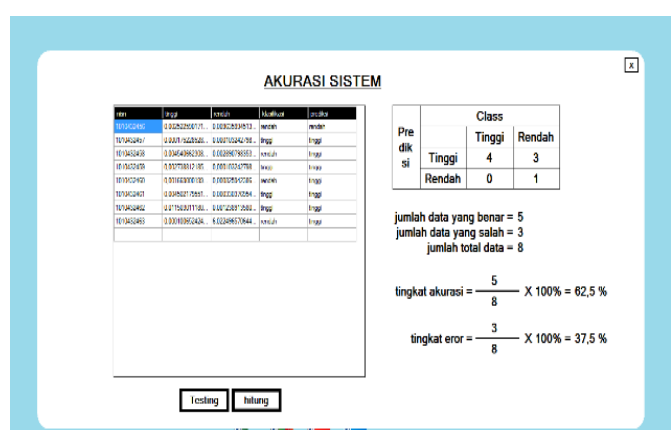

Gambar 10. Menu Laporan Hasil Prediksi (Akurasi)

yang menampilkan hasil prediksi dari inputan dari menu formulir 1. Menu ini memiliki beberapa komponen yaitu nama sekolah, judul laporan, tgl cetak, dan data hasil testing di menu formulir 1. Untuk menjalankan menu laporan hasil prediksi, terlebih dahulu masuk menu utama kemudian pilih menu prediksi kedisiplinan selanjutnya pilih menu formulir 1 . Di menu formulir 1 silakan klik tombol print maka menu laporan hasil prediksi akan tampil.

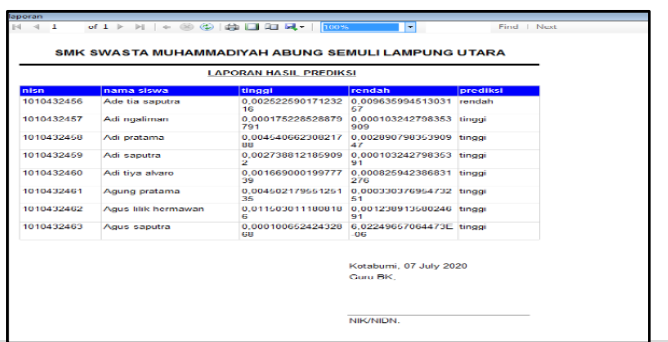

\subsection{Menu Laporan Hasil Prediksi (akurasi)}

menu laporan hasil prediksi (akurasi) merupakan menu yang menampilkan hasil prediksi dari inputan dari menu formulir 2 . Menu ini memiliki beberapa komponen di antaranya yaitu nama sekolah, judul laporan, tgl cetak, informasi akurasi, informasi eror dan data hasil testing di menu formulir 2. Untuk menjalankan menu laporan hasil prediksi, terlebih dahulu masuk menu utama kemudian pilih menu prediksi kedisiplinan selanjutnya pilih menu formulir 2. Di menu formulir 2 silakan klik tombol print maka menu laporan hasil prediksi akan tampil.

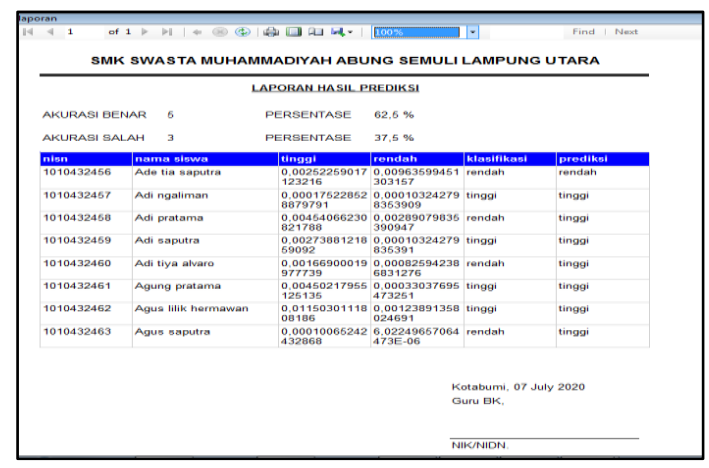

Gambar 8. Menu Akurasi Sistem

\section{KESIMPULAN DAN SARAN}

\section{a. Kesimpulan}

Berdasarkan hasil penelitian, maka penulis dapat menarik kesimpulan sebagai berikut:

1. Aplikasi data mining yang menggunakan metode naive bayes berhasil di bangun dan dapat di gunakan oleh sekolah untuk menentukan potensi kedisiplinan siswa.

2. Sistem aplikasi ini dapat menampilkan informasi klasifikasi tinggi dan rendah potensi tingkat kedisiplinan siswa.

3. Dari hasil uji coba data testing yang berjumlah 8 record dengan 10 variabel menghasilkan keakuratan sebesar $63 \%$ dan eror sebesar $38 \%$, sehingga dapat di simpulkan bahwa sistem ini sudah baik untuk di lihat dari data yang di dapat berdasarkan kesesuaiannya. 


\section{b. Saran}

Hal hal yang di harapkan untuk kedepannya dalam penggunaan algoritma naive bayes untuk pengklasifikasian potensi tingkat kedisiplinan siswa ini, dapat di bandingkan dengan algoritma yang lain dengan studi yang sama, sehingga bisa membandingkan algoritma mana yang lebih akurat untuk bisa di pakai dengan baik kedepannya.

\section{DAFTAR PUSTAKA}

[1] Arsaf, N. A. (2015). Faktor penyebab pelanggaran tata tertib (studi pada siswa di sma negeri 18 makassar). Jurnal Sosialisasi Pendidikan Sosiologi-FIS UNM Peserta, 02(1), 15.

[2] Diagram alir - Wikipedia bahasa Indonesia, ensiklopedia bebas. (n.d.). Retrieved March 30, 2020, from https://id.wikipedia.org/wiki/Diagram alir

[3] Hasibuan, N. A., Silalahi, N., Nasution, S. D., Sutiksno, D. U., Nurdiyanto, H., Buulolo, E., Ambon, P. N., Pendahuluan, I., \& Mining, A. D. (2017). Implementasi Data Mining Untuk Pengaturan Layout. 4(4), 6-11.

[4] Hayuningtyas, R. Y. (2019). Penerapan Algoritma Naïve Bayes untuk Rekomendasi Pakaian Wanita. Jurnal Informatika, 6(1), 18-22. https://doi.org/10.31311/ji.v6i1.4685

[5] Iskandar, D., \& K. Suprapto, Y. (2015). Perbandingan Akurasi Klasifikasi Tingkat. Jurnal Ilmiah NERO, 2(1), 37-43.

https://doi.org/10.21107/NERO.V2I1. 42

[6] Kasus, S., Dehasen, U., Haryati, S., Sudarsono, A., \& Suryana, E. (2015). IMPLEMENTASI DATA MINING UNTUK MEMPREDIKSI MASA STUDI MAHASISWA MENGGUNAKAN ALGORITMA C4 . 5. 11(2), 130-138.

[7] Kurniawan, H., Apriliah, W., Kurniawan, I., Firmansyah, D., Informasi, S., \& Pinjam, S. (2020). Penerapan Metode Waterfall Dalam Perancangan Sistem Informasi Penggajian Pada Smk Bina Karya Karawang. Jurnal Rosma, 14(4), 13-23.

[8] Nurabadi, A., Malang, U. N., \& Malang, J. S.
(2020). Hubungan keikutsertaan ekstrakurikuler pramuka dengan tingkat kedisiplinan siswa. 3, 11-18.

[9] Pangkalan data - Wikipedia bahasa Indonesia, ensiklopedia bebas. (n.d.). Retrieved March 30, 2020, from https://id.wikipedia.org/wiki/Pangkala n_data

[10] Sarkawi, D., \& Sekretari, P. S. (2018). PERANCANGAN APLIKASI PENJUALAN DENGAN METODE WATERFALL. Jurnal PETIR, 11(1), 9-24.

[11] Sholichin, A. (2016). Pemrograman Web dengan PHP dan MySQ. 14. https://books.google.co.id/books?id=k cD4BQAAQBAJ\&lpg=PA1\&dq=php $\& p g=\mathrm{PA} 1 \# \mathrm{v}=$ onepage $\& \mathrm{q}=\mathrm{php} \& \mathrm{f}=$ fals e

[12] Siregar, A. M., Kom, S., Puspabhuana, M. K. D. A. N. A., Kom, S., \& Kom, M. (2017). DATA MINING: Pengolahan Data Menjadi Informasi dengan RapidMiner. CV Kekata Group.

[13] Studi, P., Informasi, S., \& Bayes, N. (2020). Implementasi Nä̈ve Bayes Untuk Memprediksi Waktu Tunggu Alumni Dalam Memperoleh Pekerjaan. 131134.

[14] Visual Basic .NET - Wikipedia bahasa Indonesia, ensiklopedia bebas. (n.d.). Retrieved March 29, 2020, from https://id.wikipedia.org/wiki/Visual_B asic_.NET

[15] Wirantasa, U. (2017). Pengaruh Kedisiplinan Siswa Terhadap Prestasi Belajar Matematika. Formatif: Jurnal Ilmiah Pendidikan MIPA, 7(1), 83-95. https://doi.org/10.30998/formatif.v7i1. 1272 